\title{
$\mathrm{UiO}$ : Det juridiske fakultet
}

\section{Kapitaliseringsrenten og kravet om full erstatning ved utmåling av bruksverdierstatning på ekspropriasjonsrettens område}

Kandidatnummer: 808

Leveringsfrist: $\quad 25.04 .2015$

Antall ord: $\quad 17066$ 


\section{Innholdsfortegnelse}

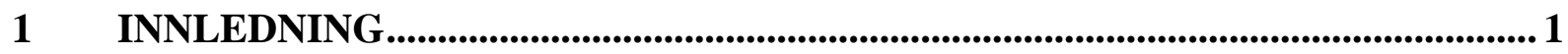

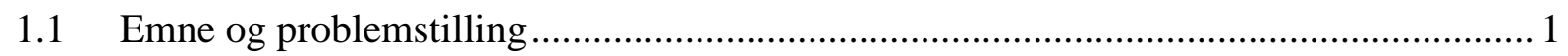

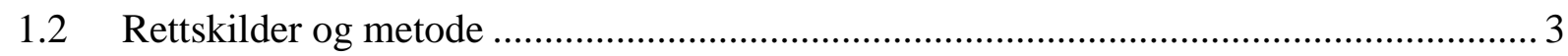

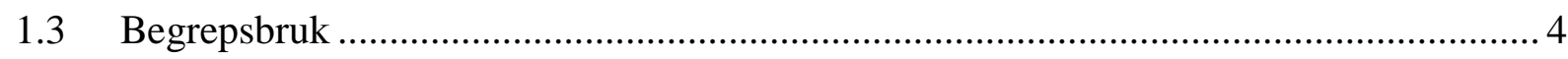

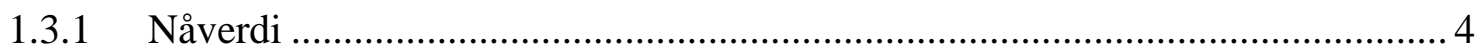

1.3.2 Nominelle og reelle renter / nominell verdi og realverdi ................................ 4

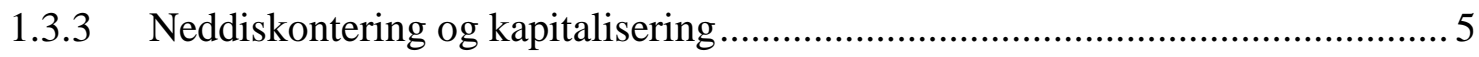

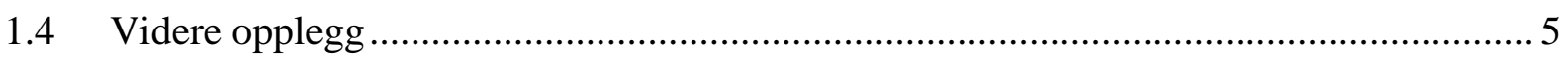

2 KRAVET OM FULL ERSTATNING

3 KOMPONENTER SOM LIGGER TIL GRUNN FOR FASTSETTELSEN AV RENTENIVÅ............................................................................................................ 8

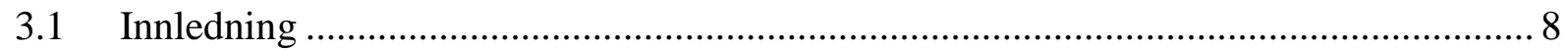

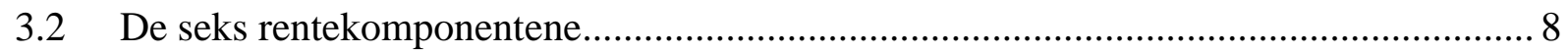

3.3 Høyesteretts vurdering av hvilke komponenter som skal legges til grunn for

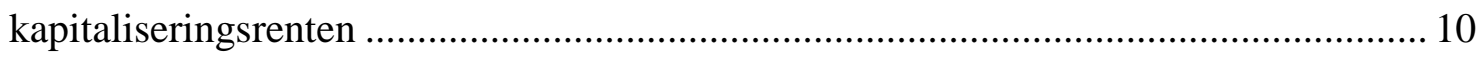

4 NOMINELL RENTE ELLER REALRENTE? ............................................... 11

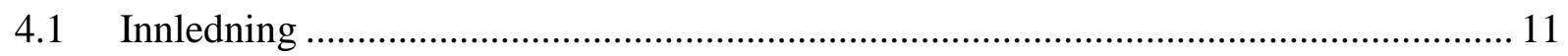

4.2 Utviklingen i rettspraksis før Kreutzer-dommen. ...................................................... 12

4.3 Kritikken i kjølvannet av rettspraksis før Kreutzer-dommen ..................................... 18

4.4 Høyesteretts vurdering av inflasjonskompensasjon i Kreutzer-dommen ..................... 21

4.5 Nominell rente og realrente på ekspropriasjonsrettens område .................................... 22

5 KOMPENSASJON FOR FORVENTET REALLØNNSVEKST ........................... 23

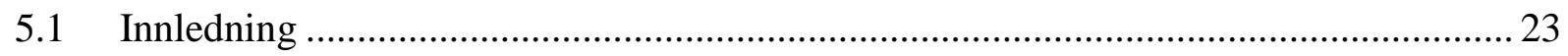

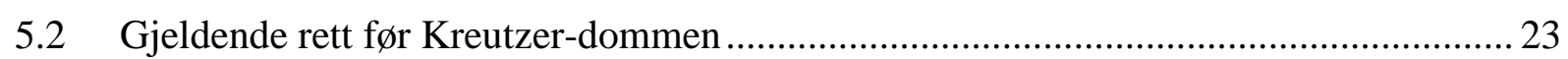

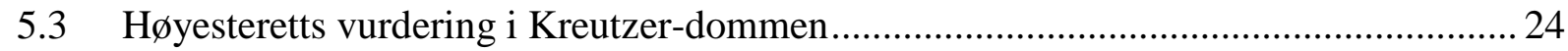

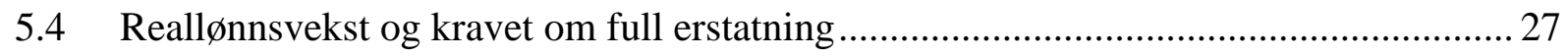

5.5 Reallønnsvekst på ekspropriasjonsrettens område................................................... 28

6 INNTEKTSUSIKKERHET OG AKTUARISK RISIKO ...................................... 28

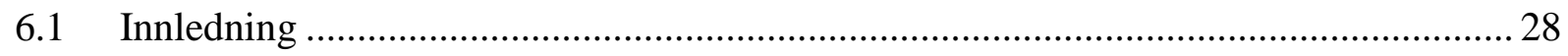

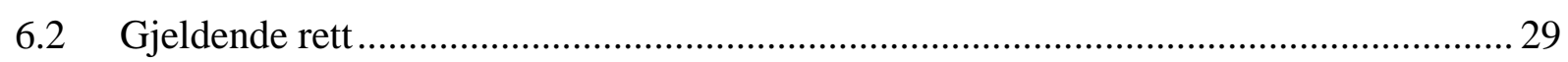

6.3 Risiko for manglende innfrielse og kravet om full erstatning. ...................................... 30 
6.4 Risiko for manglende innfrielse på ekspropriasjonsrettens område

7 TILPASNINGSPLIKTEN OG VALG AV INVESTERINGSOBJEKTER ............ 33

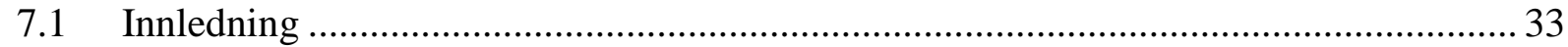

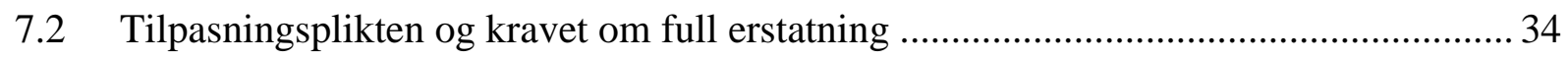

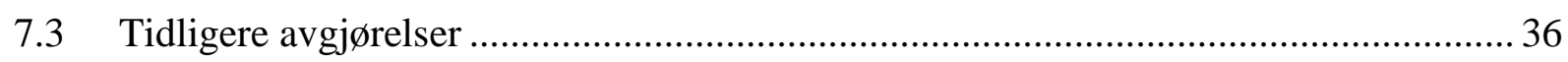

7.4 Tilpasningsplikten og valg av investeringsobjekter i Kreutzer-dommen ...................... 40

7.5 Tilpasningsplikten og valg av investeringsobjekter på ekspropriasjonsrettens område 43

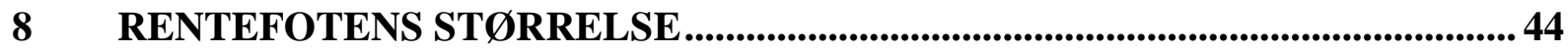

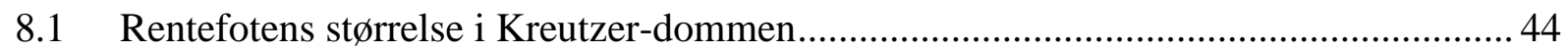

8.2 Rentefotens størrelse på ekspropriasjonsrettens område ............................................. 46

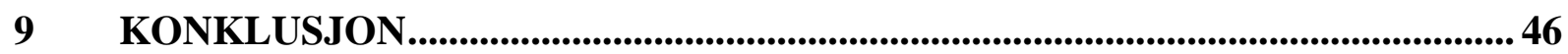

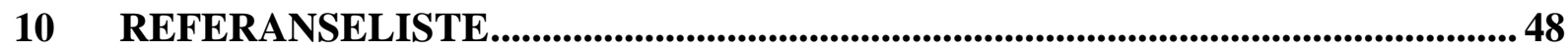




\section{Innledning}

\subsection{Emne og problemstilling}

Emnet for avhandlingen er kapitaliseringsrenten som benyttes ved utmåling av bruksverdierstatning etter ekspropriasjonserstatningsloven $\S 6$.

Grunnloven $§ 105$ slår fast at ekspropriaten har krav på full erstatning. Begrunnelsen for kravet er først og fremst reparasjonshensynet. Det økonomiske tapet ekspropriaten lider som følge av at eiendommen eksproprieres, skal repareres gjennom utbetaling av et pengebeløp. Ekspropriaten skal verken ha mer eller mindre enn det økonomiske tapet erstattet. Ved utmåling av bruksverdierstatning knytter det seg usikkerhet, og domstolen må foreta en skjønnsmessig avveining av hva avkastningen til den enkelte ekspropriat ville vært hvis man tenker ekspropriasjonen borte. Med avkastning forstås differansen mellom ekspropriatens hypotetiske inntekter og utgifter hvis man tenker at ekspropriasjonen ikke har funnet sted. Det er dette beløpet som utgjør ekspropriatens $\varnothing$ konomiske tap. Erstatningen skal som hovedregel utbetales som et engangsbeløp, ikke i årlige terminer som tilsvarer inntektsstrømmen. Dette innebærer at ekspropriaten får rådighet over erstatningsbeløpet før det $\varnothing$ konomiske tapet oppstår. Hvis den årlige tapte avkastning ikke kapitaliseres til en nåverdi, vil ekspropriaten kunne oppnå renteavkastning på pengene. Ekspropriaten vil dermed få mer enn full erstatning. Dette nødvendiggjør at erstatningsbeløpet må diskonteres ned til en nåverdi. Hvis derimot rentefoten settes høyere enn den avkastningen ekspropriaten vil ha ved å disponere pengene, vil ekspropriaten få mindre enn sitt fulle økonomiske tap erstattet.

Valget av rentenivå er ikke fastlagt av lovgiver. Det er dermed opp til domstolene å avgjøre hvilken rente som skal legges til grunn ved utmålingen. I Rt. 1981 s. 138 (Sevaldsen) fastslo Høyesterett at det skulle legges til grunn en kapitaliseringsrente på $6 \%$. Denne rentefoten ble endret i Rt. 1993 s. 1524 (Ølberg), hvor Høyesterett nedjusterte kapitaliseringsrenten til $5 \%$. Denne rentefoten er blitt lagt til grunn i senere praksis og er i teorien blitt omtalt som "prejudikatrenten". ${ }^{1}$ Rentefotens størrelse og begrunnelsen for den er i teorien blitt kraftig kritisert. Bakgrunnen for kritikken er todelt. For det første er kritikken rettet mot domstolens vurderinger av hvilke komponenter kapitaliseringsrenten skal bestå av. For det annet er det hevdet at kapitaliseringsrenten er satt for høyt, og dermed ikke leder til oppfyllelse av kravet om full erstatning. Høsten 2014 var spørsmålet om kapitaliseringsrentefoten igjen oppe for Høyesterett i Rt. 2014 s. 1203 (Kreutzer). Høyesterett fravek her Ølberg-dommen, og la til

\footnotetext{
${ }^{1}$ Eide 2011 på side 126.
} 
grunn en kapitaliseringsrente på $4 \%$. Alle de ovennevnte dommene gjaldt fastsettelsen av kapitaliseringsrenten på personskadeerstatningsrettens område.

En relevant problemstilling er hvorvidt avgjørelsene på personskadeerstatningsrettens område har betydning på ekspropriasjonsrettens område. Flåmyra-kjennelsen ${ }^{2}$ gjaldt spørsmål om kapitaliseringsrenten ved utmåling av bruksverdierstatning for skog. Flertallet i overskjønnet hadde satt kapitaliseringsrenten til $4 \%$. Mindretallet la til grunn at erstatningen måtte kapitaliseres med en rente på 5,5 \%. Høyesterett opphevet overskjønnet som følge av mangelfulle skjønnsgrunner. I kjennelsen slår Høyesterett fast at kapitaliseringsrenten som praktiseres ved beregning av tap i fremtidig erverv ved skade på person, vil kunne gi veiledning for fastsettelsen av kapitaliseringsrenten for bruksverdierstatning for skog. ${ }^{3}$

Uttalelsene i kjennelsen har blitt lagt til grunn i senere saker hvor spørsmålet om kapitaliseringsrenten på ekspropriasjonserstatningsrettens område har vært oppe for Høyesterett. Torsæter-kjennelsen ${ }^{4}$ og Gråfjellet-kjennelsen ${ }^{5}$ gjaldt også spørsmålet om kapitaliseringsrenten ved bruksverdierstatning for skog. Førstvoterende legger til grunn at Flåmyra-kjennelsen gav anvisning på at rentesatsen fastslått i Ølberg-dommen, også skal anvendes ved kapitalisering av bruksverdierstatning for skog. ${ }^{6}$ I Gråfjellet-kjennelsen legger førstvoterende til grunn at det foreligger "fast Høyesterettspraksis for at det i saker om erstatning ved ekspropriasjon eller fredning av fast eiendom, personskadesakene og andre saker hvor det må foretas en neddiskontering av et fremtidstap som hovedregel anvendes en kapitaliseringsrente på fem prosent". ${ }^{7}$

Rettspraksis før Kreutzer-dommen ${ }^{8}$ viser dermed at den samme kapitaliseringsrenten som benyttes på personskadeerstatningsrettens område, også skal benyttes på ekspropriasjonserstatningsrettens område. Det kan imidlertid stilles spørsmål ved om vurderingene Høyesterett foretar i Kreutzer-dommen tilsier et annet resultat ved fastsettelsen av kapitaliseringsrenten innenfor ekspropriasjonserstatningsretten. Som følge av at personskaderett og ekspropriasjonsrett er to forskjellige rettsområder, vil vurderingene av hvilke komponenter som skal legges til grunn for kapitaliseringsrenten kunne være

\footnotetext{
${ }^{2}$ Rt. 1994 s. 557.

${ }^{3}$ Rt. 1994 s. 557 på side 563.

${ }^{4}$ Rt. 1997 s. 428.

${ }^{5}$ Rt. 2008 s. 195

${ }^{6}$ Rt. 1997 s. 428 på side 433.

${ }^{7}$ Rt. 2008 s. 195 i avsnitt 93.

${ }^{8}$ Rt. 2014 s. 1203.
} 
annerledes. Hvorvidt det foreligger forhold ved Høyesteretts vurderinger som tilsier et annet resultat på ekspropriasjonsrettens område, vil bli vurdert løpende i avhandlingen.

Målet for avhandlingen er å foreta en analyse og vurdering av hvorvidt ekspropriaten etter gjeldende rett gis full erstatning. Det vil ikke bli foretatt en økonomisk vurdering av hvorvidt kapitaliseringsrentens størrelse er riktig. Sentralt er Høyesteretts vurderinger av hvilke komponenter kapitaliseringsrenten skal bestå av. Analysen kan deles inn i tre deler. For det første må innholdet i kravet om full erstatning fastlegges. For det annet må det foretas en analyse av rettspraksis som tar stilling til spørsmålet om kapitaliseringsrenten. Sentralt vil her være en analyse av dommen inntatt i Rt. 2014 s. 1203 (Kreutzer), men rettsutviklingen i tiden før dommen er også av betydning. For det tredje må det vurderes hvilken virkning Kreutzerdommen har ved utmåling av bruksverdierstatning på ekspropriasjonserstatningsrettens område.

Høyesterett har i flere avgjørelser åpnet for å benytte en annen kapitaliseringsrente enn prejudikatrenten i visse tilfeller. Et annet spørsmål som er nært knyttet opp til spørsmålet om kapitaliseringsrenten er spørsmålet om behandlingen av skatteulempen. Skatteulempen innebærer at den erstatningsberettigede må betale skatt på renteinntektene fra erstatningen samt eventuell formuesbeskatning. Som følge av avhandlingens størrelse vil disse spørsmålene ikke behandles.

\subsection{Rettskilder og metode}

Sentralt ved utmålingen av bruksverdierstatning ved ekspropriasjon er Grunnloven $§ 105$ og ekspropriasjonserstatningsloven $\S 6$. Grunnloven $\S 105$ fastslår at ekspropriaten har krav på "fuld erstatning". Ekspropriasjonsloven $\S 6$ definerer hva som ligger i begrepet bruksverdierstatning. Felles for begge bestemmelsene er at de gir liten veiledning for spørsmålet om kapitaliseringsrentens størrelse. Rettspraksis omkring utmåling av bruksverdierstatning vil dermed være avgjørende for denne avhandlingen. Som vist ovenfor har Høyesterett lagt til grunn at kapitaliseringsrenten på personskadeerstatningsrettens område i utgangspunktet også skal anvendes ved utmåling av bruksverdierstatning. ${ }^{9}$ Rettskilder på personskadeerstatningsrettens område vil dermed være av betydning for avhandlingen. Sentralt er skadeserstatningsloven § 3-1 og tilhørende forarbeider, rettspraksis og juridisk litteratur. I tillegg til disse rettskildene finnes det flere artikler i juridiske tidsskrifter som omhandler spørsmålet om kapitaliseringsrenten.

\footnotetext{
${ }^{9}$ Rt. 1994 på s. 557, Rt. 1997 s. 428.
} 
Avhandlingen er hovedsakelig en presentasjon av gjeldende rett. I tilknytning til spørsmålet om gjeldende rett leder til at kravet om full erstatning oppnås, vil det foretas vurderinger av hvordan retten bør være.

\subsection{Begrepsbruk}

Under følger en forklaring av enkelte fag økonomiske uttrykk som vil benyttes i avhandlingen.

\subsubsection{Nåverdi}

Nåverdi er det fremtidige tap målt i dagens pengeverdi. Den fremtidige kontantstrømmen (tilsvarende avkastning på avstått areal) må beregnes til en verdi tilsvarende dagens kroneverdi.

Renten skal gjøre det mulig for den erstatningsberettigede å ta ut et beløp tilsvarende det årlige tapet i hvert av de årene tapet oppstår, og på slutten av perioden skal kapitalen være brukt opp. ${ }^{10}$

\subsubsection{Nominelle og reelle renter / nominell verdi og realverdi}

Nominell rente er den faktiske avkastningen långiver oppnår når det tas hensyn til at pengeverdien har endret seg. Realrenten er den reelle avkastningen långiver får når man ser bort fra inflasjon. Realrenten er dermed tilnærmet lik differansen mellom nominell rente og inflasjon. ${ }^{11}$ Hvis n er nominell rente, $r$ er realrente og i er inflasjon, får man følgende formel: ${ }^{12}$

$\mathrm{r}=(\mathrm{n}-\mathrm{i}) /(1+\mathrm{i})$

$\mathrm{n}=\mathrm{r}+\mathrm{i}+(\mathrm{r} \times \mathrm{i})$

Forskjellen mellom nominell rente og realrente kan illustreres med følgende eksempel. 50000 kroner plasseres i en bankkonto som gir en nominell rente på $4 \%$ per år. Det legges til grunn at den årlige inflasjonen er $2 \%$. Etter 1 år har man 50000 kroner x 1,04 = 52000 kroner. Dette kan betegnes som den nominelle verdien av innskuddet etter ett år. Beløpet må korrigeres for inflasjonen. Den reelle verdien av innskuddet er dermed 52000 kroner / 1,02= 50980 kroner. Den reelle verdiøkningen er dermed 980 kroner. Beløpet utgjør 1,96\% av det opprinnelige innskuddet. Selv om den reelle renten er $4 \%$, er realrenten ikke større enn $1,96 \%$.

\footnotetext{
${ }^{10}$ Rt. 1993 s. 1524 på side 1530.

${ }^{11}$ Hylland 1995 s. 42.

${ }^{12}$ Formel hentet fra NOU 1994:20 s. 22.
} 
Når man benytter en nominell rente ved kapitalisering benyttes det nominalistiske prinsipp. Hvis realrenten legges til grunn benyttes det valoriske prinsipp. Høyesterett la tidligere til grunn det nominalistiske prinsipp ved kapitaliseringen av fremtidig tap. Som avhandlingen vil vise bør ikke disse prinsippene kombineres i det samme regnestykket. I teorien er det blitt hevdet at Høyesterett faktisk har begått denne feilen. Dette vil bli redegjort for nærmere under avhandlingens punkt 3 .

\subsubsection{Neddiskontering og kapitalisering}

Med kapitalisering forstås det å fastsette nåverdien av inntekter som ville kommet suksessivt i en rekke år fremover. Det skjer da en diskontering av det årlige beløpet, idet man trekker fra fordelen ved straks å disponere hele erstatningsbeløpet. Kapitaliseringsfaktoren multipliseres med det årlige tapet. Denne faktoren består av to komponenter: En rentefot og det antallet år inntekten ville kommet. ${ }^{13}$ Desto høyere rente som legges til grunn, desto lavere vil nåverdien av det årlige tapet være. Dette kan illustreres med et eksempel: En erstatningsberettiget vil lide et tap på 100000 kroner per år ti år frem i tid. Summen av de årlige tapene blir da 1000 000 kroner. Hvis det legges til grunn en årlig rente på 5 \% vil erstatningen bli som følger:

$$
\begin{aligned}
& 100000 \times\left(1 / 1,05+1 / 1,05^{2}+1 / 1,05^{3}+1 / 1,05^{4}+1 / 1,05^{5}+1 / 1,05^{6}+1 / 1,05^{7}+1 / 1,05^{8}+\right. \\
& \left.1 / 1,05^{9}+1 / 1,05^{10}\right)=\text { ca. } 772000
\end{aligned}
$$

Differansen mellom 1000000 kroner og 772000 kroner (228 000 kroner) utgjør den fordelen den erstatningsberettigede har ved å disponere beløpet fra år 0 , altså før tapene anses lidt.

Legges det til grunn en rente på $4 \%$ vil den erstatningsberettigede få utbetalt ca 811000 kroner. Dette viser at valg av rentefot er avgjørende i forhold til hvor stor erstatning som utbetales. Selv mindre endringer av rentefoten vil kunne utgjøre store forskjeller for den erstatningsberettigede.

\section{$1.4 \quad$ Videre opplegg}

Avhandlingen er delt inn i syv kapitler i tillegg til en innledende og avsluttende del. I kapittel 2 vil innholdet i kravet om full erstatning fastlegges. Kapittel 3 inneholder en nærmere forklaring av rentebegrepet. Det gis her en oversikt over hvilke komponenter fagøkonomer mener skal legges til grunn for kapitaliseringsrenten, og hvilke spørsmål knyttet til

\footnotetext{
${ }^{13}$ Lødrup m. fl. 2009 s. 488.
} 
kapitaliseringsrenten som Høyesterett måtte ta stilling til i Kreutzer-dommen. ${ }^{14}$ I kapittel 4 til kapittel 8 vil det foretas en analyse og vurdering av gjeldende rett. Inndelingen følger de spørsmålene Høyesterett tok stilling til i Kreutzer-dommen.

\section{Kravet om full erstatning}

For å besvare problemstillingen om gjeldende rett leder til oppfyllelse av kravet om full erstatning, må det redegjøres noe nærmere for hva som ligger i dette begrepet.

På ekspropriasjonsrettens område fremgår kravet om full erstatning av Grunnloven $§ 105$. I dette ligger det et krav om at "erstatningen skal fastsettes slik at ekspropriaten ikke blir påført noe $\varnothing$ konomisk tap ved inngrepet - han skal settes i den stilling han ville vært om inngrepet ikke hadde funnet sted", jamfør Ulvåkjølen-dommen. ${ }^{15}$ Utmåling av erstatning etter bestemmelsene i ekspropriasjonserstatningsloven skal søke å tilfredsstille Grunnlovens krav om "fuld erstatning".

Erstatningen skal fastsettes til hvilket tap ekspropriaten vil lide i fremtiden som følge av at ekspropriasjonen finner sted. Dette innebærer at avgjørelsesmyndigheten må ta stilling til hvilket tap det er sannsynlig at ekspropriaten vil lide som følge av ekspropriasjonen. Denne vurderingen er i stor grad beheftet med usikkerhet, da det ikke er mulig å spå hvordan fremtiden ser ut. Svaret på om den enkelte erstatningsberettigede faktisk har fått full erstatning vil først kunne påvises i slutten av den rekke med år hvor ekspropriaten lider tap.

I Ølberg-dommen uttalte Høyesterett at begrepet "full erstatning" er et juridisk begrep, ikke et eksakt økonomisk begrep. ${ }^{16}$ Denne poengteringen har to viktige sider. For det første har det juridiske begrepet et snevrere innhold enn det $\varnothing$ konomiske begrepet, ved at erstatningen fastsettes med lavere beløp enn det som ville fulgt av rent matematiske beregninger. ${ }^{17}$ På ekspropriasjonsrettens område vil kravet om full erstatning tåle flere innskrenkninger. Ved utmåling av bruksverdien må det foretas justeringer for verdiendringer som skyldes blant annet ekspropriasjonstiltaket og ulike offentlige investeringer som kan påvirke verdien av fast eiendom. ${ }^{18}$ Ulemper på gjenværende eiendom vil heller ikke erstattes fullt ut. ${ }^{19}$ Det skal også

\footnotetext{
${ }^{14}$ Rt. 2014 s. 1203.

${ }^{15}$ Rt. 1992 s. 217, på s. 225.

${ }^{16}$ Rt. 1993 s. 1524 , på s. 1532.

${ }^{17}$ Syse m. fl. 2011 s. 359.

${ }^{18}$ Jf. orvl. $§ 5$ tredje og fjerde ledd, jf. § 6 annet ledd.

${ }^{19}$ Jf. orvl. § 8 .
} 
gjøres fradrag i fordeler på gjenværende eiendom. ${ }^{20}$ Ekspropriatens tilpasningsplikt innebærer også et avvik mellom det $\varnothing$ konomiske og juridiske begrepet.

For det annet medfører det juridiske begrepet en skjønnsmessig vurdering. ${ }^{21}$ For å vurdere et $\emptyset$ konomisk tap rent matematisk må det legges til grunn premisser for utregningen. Ved utmåling av erstatning bygger disse premissene på vurderinger av juridisk karakter. For det første må faktum fastlegges. Videre må faktum anvendes på den aktuelle rettsregelen.

Som følge av disse forskjellene mellom det økonomiske begrepet og det juridiske begrepet er det blitt hevdet i teorien at kravet om full erstatning også kan oppfattes som et rettsanvendelsesresultat. ${ }^{22}$ I NOU 1994:20 erkjennes det at flere erstatningsbeløp i ettertid vil vise seg ikke å tilfredsstille "full erstatning" som en økonomisk størrelse. Uavhengig av denne forskjellen uttrykker Høyesterett et klart mål om at det juridiske kravet om full erstatning skal ligge så tett opp mot det økonomiske begrepet som mulig. Dette gjelder også ved fastsettelsen av kapitaliseringsrenten. I Ølberg-dommen uttrykker Høyesterett at målet er "å finne frem til den rente som, dersom nåtidsverdien investeres til denne renten, gjør det mulig for skadelidte å ta ut et beløp tilsvarende det årlige tapet i hvert av de årene tapet oppstår". ${ }^{23}$

Enkelte hensyn som gjør seg gjeldende ved fastsettelsen av kapitaliseringsrenten, innebærer at kravet om full erstatning ikke vil kunne oppnås i alle tilfeller. For det første har Høyesterett slått fast at kapitaliseringsrenten skal være generell. ${ }^{24}$ Dette innebærer at den skal kunne komme til anvendelse ved utmåling av erstatning for fremtidig tap uavhengig av faktum i den enkelte sak. Enkelte erstatningsberettigede vil kunne få mer enn sitt fulle tap erstattet, og andre mindre. For det annet har Høyesterett slått fast at kapitaliseringsrenten ikke vil være gjenstand for hyppige endringer av domstolene. ${ }^{25}$ Kapitaliseringsrenten vil dermed ikke kunne følge skift i rentenivået.

Avhandlingen vil i hovedsak fokusere på hvorvidt gjeldende rett er egnet til å oppfylle målsettingen om å stille den erstatningsberettigede i samme situasjon som tilfellet hadde vært hvis ekspropriasjonen eller skaden ikke hadde funnet sted.

\footnotetext{
${ }^{20}$ Jf. orvl. $§ 9$.

${ }^{21}$ Rt. 1993 s. 1524 , på s. 1532.

${ }^{22}$ Syse m. fl. 2011 s. 359.

${ }^{23}$ Rt. 1993 s. 1524 , på side 1530.

${ }^{24}$ Rt. 2014 s. 1203 i avsnitt 99.

${ }^{25}$ Rt. 2014 s. 1203 i avsnitt 99.
} 


\section{Komponenter som ligger til grunn for fastsettelsen av rentenivå}

\subsection{Innledning}

Rente kan betegnes som prisen for penger. Når penger overføres fra kreditor til debitor, kan renten sees på som prisen debitor må betale for å råde over pengene. Kreditor mister rådigheten over pengene og vil dermed ikke kunne investere disse for å oppnå avkastning. Komponentene og dermed størrelsen i renten vil variere fra kreditor til kreditor. En kreditor som låner ut penger uten sikkerhet for at tilbakebetaling skjer, vil ofte kreve høyere rente enn en kreditor som låner ut penger mot sikkerhet. Denne usikkerhet representerer en kostnad for kreditor, som gjenspeiler seg i en høyere rente. Eide nevner seks ulemper som kreditor gjennom renten vil søke å få kompensasjon for. ${ }^{26}$ Disse ulempene vil bli behandlet i punkt 3.2. Desto flere av ulempene kreditor $\varnothing n s k e r$ kompensasjon for, desto høyere vil renten normalt være.

I punkt 3.3 gis det en kort oversikt over hvordan Høyesterett tidligere har tilnærmet seg spørsmålet om hvilke komponenter kapitaliseringsrenten skal bestå av. I tillegg gis det en oversikt over faktum og spørsmålene Høyesterett måtte ta stilling til i Kreutzer-dommen.

\subsection{De seks rentekomponentene}

(1) Den rene likviditetsavståelse. ${ }^{27}$ Kreditor mister ved en overføring rådigheten over pengene, og dermed også muligheten til å investere pengene. En potensiell avkastning ved alternativ investering av pengene forsvinner. Ved erstatningsutmålingen for fremtidig tap representerer likviditetsavståelsen det forhold at erstatningen utbetales som et engangsbeløp før tapet kan anses lidt. Dette er en ulempe for kreditor, som kunne investert pengebeløpet i tiden frem til tapet faktisk lides. Ulempen speiles av en fordel for den erstatningsberettigede, ved at erstatningsbeløpet kan investeres eller forbrukes uten lån før tapet er lidt.

(2) Binding av likviditet. ${ }^{28}$ Binding av likviditet over en lengre periode vil normalt avspeile seg i en høyere rente, da pengene ikke kan investeres alternativt eller forbrukes. I forhold til fastsettelse av kapitaliseringsrenten er spørsmålet hvorvidt ekspropriaten skal måtte foreta bindende plassering av erstatningsbeløpet over en

\footnotetext{
${ }^{26}$ Eide 1995a s. 60.

${ }^{27}$ Eide 1995a s. 60.

${ }^{28}$ Eide 1995a s. 60.
} 
kortere eller lengre periode. Tapets varighet bør her være avgjørende. Hvis tapet på ekspropriatens hånd oppstår om 20 år, bør det kunne kreves at ekspropriaten binder likviditeten slik at høyere rente oppnås.

(3) Administrasjonskostnader. ${ }^{29}$ Dette er kostnader som er nødvendig for å oppnå avkastning på pengene, som for eksempel innsamling av informasjon om plasseringsmuligheter og ved inngåelse og avvikling av avtaler med videre.

(4) Risiko for manglende innfrielse. ${ }^{30}$ Siden det $\varnothing$ konomiske tapet ikke er lidt på utmålingstidspunktet, knytter det seg usikkerhet knyttet til om tapet vil oppstå og i så tilfelle til tapets størrelse. Denne komponenten vil variere avhengig av risikoen som er forbundet med de årlige tap. Hvis de årlige tap kan anslås med sikkerhet, tilsier dette at erstatningsbeløpet bør plasseres på en sikker måte, for eksempel i en bankkonto. ${ }^{31}$ Omvendt, hvis de årlige tap er usikre, bør ekspropriaten akseptere at erstatningsbeløpet plasseres på en mer usikker måte, for eksempel i aksjer. Desto mer usikkerhet som er knyttet til tapenes eksistens, desto høyere bør rentefoten settes.

(5) Verdiforringelse av beløpet ved inflasjon. ${ }^{32}$ Pengenes verdi kan endre seg over tid. Hvis det generelle prisnivået går opp, så vil verdien av et gitt kronebeløp gå ned. Dette betegnes som inflasjon. I inflasjonstider vil et $\varnothing$ konomisk tap frem i tid regnet etter dagens prisnivå ikke være justert for inflasjonen. Det kan dermed ikke benyttes en nominell rente som grunnlag for kapitaliseringsrenten. Hvis derimot de årlige tapene er utmålt etter løpende priser, altså at det er tatt høyde for forventet prisstigning, vil det være riktig å benytte en nominell rentesats for å komme frem til nåverdien.

(6) Usikkerhet om utviklingen av realverdien av beløpet. ${ }^{33}$ Det kan hefte usikkerhet ved om det i fremtiden vil være inflasjon eller deflasjon, og hvor stor inflasjonen/deflasjonen vil være.

Som påpekt av Eide vil alle disse komponentene, med unntak av nummer 1, være forskjellige for forskjellige typer av finansobjekter. ${ }^{34}$ Dette innebærer at de faktiske rentesatsene også vil være forskjellige. Av Høyesteretts praksis er det tradisjonelt lagt til grunn den samme

\footnotetext{
${ }^{29}$ Eide 1995 a på side 60.

${ }^{30}$ Eide 1995 a på side 60.

${ }^{31}$ Eide 1995 a på side 60.

${ }^{32}$ Eide 1995 a på side 60.

${ }^{33}$ Eide 1995 a på side 60.

${ }^{34}$ Eide 1995 a på side 60.
} 
kapitaliseringsrenten på utmåling av ekspropriasjonserstatning og personskadeerstatning. Det kan vise seg forskjeller i størrelsen på de komponentene Eide nevner avhengig av om det $\emptyset$ konomiske tapet er tapt arbeidsinntekt eller tapt avkastning i skogbruket. Det kan dermed spørres om det faktisk er hensiktsmessig å benytte en felles kapitaliseringsrente på disse rettsområdene.

\subsection{Høyesteretts vurdering av hvilke komponenter som skal legges til grunn for kapitaliseringsrenten}

Høyesterett har hatt en mer skjønnsmessig tilnærming til fastsettelsen av kapitaliseringsrenten. Hvilke komponenter den erstatningsberettigede må bære ansvaret for, har delvis fremstått som et åpent spørsmål. I Ølberg-dommen legger Høyesterett til grunn at renten må fastsettes etter en "bred vurdering av de ulike anvendelses- og investeringsmuligheter som foreligger". ${ }^{35}$ Høyesterett har blitt kritisert for at elementene i denne skjønnsmessige vurderingen er blandet sammen slik at betydningen av enkeltelementer i skjønnet drukner. ${ }^{36}$ I Kreutzer-dommen fremstår Høyesteretts tilnærming til vurderingen av kapitaliseringsrenten som mer systematisk, ved at de ulike elementene blir behandlet enkeltvis.

Kreutzer-dommen gjaldt erstatningsoppgjøret etter personskade. En kvinne på 20 år hadde vært utsatt for en bilulykke. Hun ble erklært 100 prosent medisinsk og ervervsmessig ufør. Partene var enige om at den skadelidte ville ha studert juss og deretter hatt en karriere som jurist. Det var også enighet om å basere seg på lønnsstatistikken til Norges juristforbund.

Det var to sentrale spørsmål i saken. For det første måtte Høyesterett ta stilling til hvilken kapitaliseringsrentefot som skulle legges til grunn for kapitaliseringen. For det annet måtte det tas stilling til hvilket tillegg det måtte gjøres for eventuell skatteulempe forårsaket av at erstatningsbeløpet er gjenstand for beskatning.

Skadelidte hevdet at kapitaliseringsrenten skulle settes ned til to prosent. Forsikringsselskapet hevdet på sin side at kapitaliseringsrenten måtte bli stående på fem prosent.

Spørsmålene som Høyesterett måtte ta stilling til var følgende:

a. Om kapitaliseringsrenten skulle beskytte mot inflasjon. Altså om det skulle legges til grunn en realrente eller en nominell rente.

\footnotetext{
${ }^{35}$ Rt. 1993 s. 1524 på side 1533.

${ }^{36}$ Eide 2011 på side 147.
} 
b. Om det skal tas hensyn til forventet reallønnsvekst ved fastsettelse av kapitaliseringsrenten.

c. Om det skal tas hensyn til usikkerhet knyttet til om inntekt uten skaden ville inntrådt ved fastsettelsen av kapitaliseringsrenten.

d. Hvilke investeringsalternativer som legges til grunn for fastsettelse av kapitaliseringsrenten.

e. Hva den generelle kapitaliseringsrenten skal være i lys av de ovennevnte rettslige vurderingene.

f. Om det er grunnlag for å fastsette en særskilt kapitaliseringsrente fordi skadelidte har begrensede investeringsalternativer.

g. Hvilket tillegg som måtte gjøres for eventuell skatteulempe forårsaket av at erstatningsbeløpet er gjenstand for beskatning.

Inndelingen i de videre kapitlene vil følge disse spørsmålene. Spørsmålene under bokstav f og g faller utenfor spørsmålene som skal vurderes i denne avhandlingen.

Tidligere avgjørelser og kritikken i kjølvannet av denne vil bli gjennomgått løpende gjennom avhandlingen. For det første vil dette bidra til å belyse hvilke vurderinger som bør legges til grunn for at den erstatningsberettigede får full erstatning. For det annet er dette nødvendig for å vurdere Kreutzer-dommens relevans for fastsettelsen av kapitaliseringsrenten på ekspropriasjonsrettens område.

\section{Nominell rente eller realrente?}

\subsection{Innledning}

I dette punkt skal det for det første vurderes om Høyesterett i tidligere praksis har lagt til grunn en nominell rente eller en realrente ved kapitalisering av fremtidig tap. Videre skal det vurderes hva som bør legges til grunn for at den erstatningsberettigede skal få full erstatning. Avslutningsvis vil det spørres om Høyesteretts vurderinger i Kreutzer-dommen tilknytning til spørsmålet om inflasjonskompensasjon, tilsier at den erstatningsberettigede får sitt fulle tap erstattet. 


\subsection{Utviklingen i rettspraksis før Kreutzer-dommen.}

Sevaldsen-dommen er fra 1981 og gjaldt personskadeerstatning. ${ }^{37}$ Sevaldsen var 18 år gammel da han hadde blitt utsatt for en trafikkulykke. Ulykken medførte at han var å anse som $100 \%$ invalid. Saken stod mellom Sevaldsen og Gjensidige forsikring. Et sentralt spørsmål i saken var hvordan de fremtidige tapene skulle kapitaliseres. Skadelidte hevdet at de fremtidige tapene måtte kapitaliseres med en rentefot på $4 \%$. Gjensidige på sin side hevdet at kapitaliseringsrenten måtte settes til $8 \%$.

Førstvoterende slår innledningsvis fast at det må vurderes hva en langtidsrente ville bli helt frem til 2023 for at skadelidte "skal beholde den nominelle erstatning han oppnår i dag. Jeg understreker nominelle erstatning, idet jeg ikke kan se at det ved fastsettelsen av kapitaliseringsrenter også kan tas sikte på å dekke et forventet inflasjonstap." ${ }^{38}$ Dette viser at Høyesterett $\varnothing$ nsker å legge det nominalistiske prinsipp til grunn ved fastsettelsen av kapitaliseringsrenten. Høyesterett underbygger dette ved å vise til uttalelser som fremgår av erstatningslovkomiteens innstilling av 1971. Slutningen som trekkes ut fra innstillingen er at "når erstatningsutbetalingen utbetales som et engangsbeløp, vil skadelidte ha muligheten til å verdisikre erstatningsbeløpet". At skadelidte har muligheten til å verdisikre erstatningsbeløpet må anses som en selvfølge. Dette betyr imidlertid ikke at skadelidte får sitt fulle tap erstattet. Nedenfor vil det bli vist at verdisikringshensyn ikke kan tillegges vekt når selve erstatningsbeløpet skal fastsettes.

Ut fra begrunnelsen i dommen fremstår det som klart at skadelidte ikke skal gis beskyttelse for forventet inflasjon. Renten ble likevel satt til $6 \%$, noe som var lavere enn rentenivået på utmålingstidspunktet. Den nominelle renten var på ca. $12 \%$ på utmålingstidspunktet. ${ }^{39}$ Hylland hevdet dette var et tegn på at kapitaliseringsrenten skulle gi en viss inflasjonsbeskyttelse. ${ }^{40}$ Det samme gjorde Høyesterett i den senere Noem-dommen, hvor førstvoterende med henvisning til Sevaldsen-dommen uttaler følgende:

"En bemerkning i premissene som går mot at det ved "fastsettelsen av kapitaliseringsrenter også kan tas sikte på å dekke et forventet inflasjonstap", harmonerer ikke godt med det resultat man kom frem til". ${ }^{41}$

\footnotetext{
${ }^{37}$ Rt. 1981 s. 138.

${ }^{38}$ På side 147.

${ }^{39}$ Kjønstad 2003 på side 317.

${ }^{40}$ Hylland 1995 s. 60.

${ }^{41}$ Rt. 1986 s. 178 på side 187
} 
Det er vanskelig å se at rentenivået som Høyesterett la seg på i Sevaldsen-dommen, kan tas til inntekt for at kapitaliseringsrenten skulle gi inflasjonsbeskyttelse. I Sevaldsen-dommen slås det fast at renten som skal legges til grunn er en langtidsrente. Dette innebærer at rentenivået på avgjørelsestidspunktet ikke alene er avgjørende. For det annet var renten på et unormalt høyt nivå på tidspunktet for domsavsigelsen. Dette kan illustreres ved at den nominelle renten halverte seg de neste sju årene. ${ }^{42}$ Når premissene gir klart uttrykk for at det ikke skal gis inflasjonsbeskyttelse, er det nærliggende å fastslå at Høyesterett ønsket å legge en nominell rentefot til grunn for kapitaliseringsrenten.

Noem-dommen ${ }^{43}$ gjaldt utmåling av ekspropriasjonserstatning for skog. Avgjørelsen ble truffet i plenum. Høyesterett delte seg i to fraksjoner. Flertallet (9) og mindretallet (8) var i det vesentlige enige om spørsmålet knyttet til inflasjonskompensasjon. Som sitatet ovenfor viser fant førstvoterende at begrunnelsen i Sevaldsen-dommen ikke korresponderte med resultatet i saken. Førstvoterende uttrykker derfor at begrunnelsen i Sevaldsen-dommen ikke kan anses som gjeldende rett, og at han heller ikke er enig i denne begrunnelsen. ${ }^{44}$ Dette taler for at Høyesterett beveget seg bort fra det nominalistiske prinsipp ved fastsettelsen av kapitaliseringsrentefotens størrelse, og ønsket å legge en realrente til grunn for kapitaliseringsrenten.

På den annen side fremgår det ikke klart at renten som skal legges til grunn skal gi beskyttelse mot inflasjon. Rettens valg av kapitaliseringsrente ble forklart slik av førstvoterende:

"For å finne frem til den sannsynlige rente over en lang periode, må man søke å eliminere de tidsbegrensede svingninger opp og ned ved hjelp av en gjennomsnittsvurdering og komme frem til en langtidsrente.

Forutsettes for eksempel plassering i bankinnskudd, nedbetaling av lån eller lignende, vil en slik rente åpenbart måtte ligge langt under det høye rentenivået man har i dag. Med en slik langtids gjennomsnittsrente, som er anslått blant annet under hensyntagen til at dagens rentesatser er inflasjonspåvirket, vil virkningen av fall i pengeverdien i alle fall bli betydelig redusert". 45

Høyesterett bemerker bare at det skal benyttes en langtids gjennomsnittsrente, men ikke hvorvidt denne renten skal beskytte mot inflasjon eller ikke. Men førstvoterendes avvisning av uttalelsene i Sevaldsen-dommen tyder på at det skal legges en realrente til grunn.

\footnotetext{
${ }^{42}$ Kjønstad 2003 på side 317.

${ }^{43}$ Rt. 1986 s. 178.

${ }^{44}$ Side 187.

${ }^{45}$ Side 187.
} 


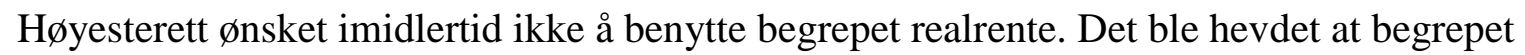
ikke var entydig ved at det ble brukt i forskjellig betydning i forskjellige saker. ${ }^{46}$

Dokumentasjonen som hadde blitt lagt frem for Høyesterett viste at realrenten i enkelte perioder var negativ. Høyesterett hevdet at det i erstatningssammenheng ikke kunne opereres med en negativ rente. Disse uttalelsene åpner for to mulige tolkningsalternativer. For det første kan det forstås som at Høyesterett rent faktisk ønsker å gi inflasjonsbeskyttelse, men at det bare er begrepet "realrente" som ikke ønskes benyttet. Alternativt kan det forstås som en avvisning av ønsket om å gi full inflasjonsbeskyttelse ved fastsettelsen av kapitaliseringsrenten. Premissene fremstår som uklare, og det er vanskelig å konkludere for dette spørsmålet. Det eneste som fremstår som ganske sikkert, er at Høyesterett ønsket å gi en viss inflasjonskompensasjon.

Ølberg-dommen ${ }^{47}$ gjaldt erstatningsutmålingen ved personskade. En syv år gammel gutt hadde blitt skadet i en trafikkulykke, og var på domstidspunktet å anse som $40 \%$ invalid. Hovedspørsmålet i saken var fastsettelse av kapitaliseringsrenten. Partene var enige om at det skulle benyttes en kapitaliseringsrente på $6 \%$ på erstatningsbeløpet frem til fylte 20 år. Skadelidte hevdet at det for tap etter 20 år måtte erstatningsutbetalingen kapitaliseres med en kapitaliseringsrente på $3 \%$. Forsikringsselskapet hevdet på sin side at hele erstatningsbeløpet måtte kapitaliseres med en rentefot på $6 \%$. Høyesterett falt ned på en rente på $5 \%$.

I de innledende premissene i dommen slår Høyesterett fast utgangspunktet om at en "må finne frem til den rente som, dersom nåtidsverdien investeres til denne renten, gjør det mulig for skadelidte å ta et beløp tilsvarende det årlige tapet i hvert av de årene tapet oppstår". ${ }^{48}$ Førstvoterende fremsetter så flere argumenter som presumptivt vil gi skadelidte denne muligheten. Her vil kun nevnes argumentene som knytter seg til spørsmålet om inflasjonskompensasjon.

For det første viser førstvoterende til Erstatningslovkomiteens utkast fra 1971:

"Spørsmålet om verdisikring av erstatningsytelser var fremme i forarbeidene til skadeserstatningslovens kapittel 3. I Innstilling fra Erstatningslovkomiteen (1971) er spørsmålet behandlet $\mathrm{i}$ forbindelse med fastsettelse av erstatning som terminvise beløp. Dersom erstatningen ble fastsatt som et engangsbeløp, mente komiteen at skadelidte selv ville kunne sørge for å verdisikre beløpet". ${ }^{49}$

\footnotetext{
${ }^{46}$ På side 187.

${ }^{47}$ Rt. 1993 s. 1524.

${ }^{48}$ På side 1530.

${ }^{49}$ På side 1530.
} 
Som Eide skriver, medfører disse uttalelsene riktighet all den tid det er den erstatningsberettigede som er ansvarlig for plassering av beløpet. ${ }^{50}$ Det er imidlertid vanskelig å forstå hvilken virkning uttalelsene skal ha ved fastsettelsen av kapitaliseringsrenten. Det kan enten forstås som det selvsagte, at den erstatningsberettigede er ansvarlig for plassering av erstatningsbeløpet. Alternativt kan det forstås som at den erstatningsberettigede har muligheten til å verdisikre erstatningsbeløpet, og dermed også sikre seg mot fremtidig prisstigning.

Høyesterett viser videre til Noem-dommen, og slår fast at både flertallet og mindretallet mente at kapitaliseringsrenten måtte fastsettes etter en "bred skjønnsmessig vurdering". Det vises så til et lengre sitat fra Noem-dommen. Dette sitatet er behandlet ovenfor, og knytter seg blant annet til førstvoterende i Noem-dommens avvisning av nominalismen i Sevaldsendommen, men også avvisningen av bruken av begrepet realrente.

Begrepet realrente hadde blitt behandlet av partene i prosedyren for Høyesterett. Førstvoterende viser til de sakkyndiges definisjon av begrepet: ${ }^{51}$

"Realrenten defineres som den del av den nominelle renten som utgjør kompensasjon for å ha avstått fra retten til å disponere over kapitalen."

Høyesterett slår så fast at kapitalisering ved bruk av realrente vil gi full kompensasjon for inflasjon. Førstvoterende mener likevel at det ved fastsettelsen av kapitaliseringsrenten reiser seg "vurderings- og valgspørsmål som definisjonen av realrentebegrepet ikke gir noe direkte svar på". ${ }^{52}$ Høyesterett mener at det er to spørsmål som ikke blir besvart gjennom definisjonen av realrente. For det første hvilken målsetting som skal legges til grunn for verdisikringen. For det annet ved hvilke plasseringsalternativer som skal tillegges vekt ved vurderingen av hvordan dette målet skal nås. Høyesterett slutter så fra Noem-dommen at "verdisikring var en del av målsettingen ved valget av kapitaliseringsrente". ${ }^{53}$ Førstvoterende kommer så med en presisering av hvordan denne målsettingen nærmere bør være. Her uttales blant annet:

"Skal skadelidte ikke stilles dårligere enn uten skaden, må erstatningsbeløpet etter mitt syn fastsettes slik at det gir skadelidte en rimelig mulighet til å sikre seg mot fall i pengeverdien. Kapitaliseringsrenten må fastsettes med dette som bakgrunn".

\footnotetext{
${ }^{50}$ Eide 2011 på side 146.

${ }^{51}$ På side 1531 og side 1532.

52 På side 1532 .

${ }^{53}$ På side 1532 .
} 
Hva som ligger i en "rimelig mulighet" sier Høyesterett lite om, men valget av et skjønnsmessig ord som "rimelig" kan tyde på at Høyesterett ikke ønsker å gi den erstatningsberettigede full inflasjonskompensasjon, bare delvis. Dette understøttes også av Høyesteretts uttalelser i forbindelse med valg av investeringsalternativer som skal ligge til grunn for kapitaliseringsrenten. Førstvoterende uttaler her at "investering i fast eiendom og i livrente har normalt vært ansett å gi god sikring mot inflasjon". ${ }^{54}$ Hvis målet for valg av investeringsalternativer er å gi god beskyttelse mot inflasjon, tyder dette på at det skal legges en nominell rente til grunn for kapitaliseringsrenten. Den erstatningsberettigede får da selv ansvar for å beskytte seg mot fremtidig inflasjon ved å investere erstatningsbeløpet i nevnte investeringsalternativer.

Høyesteretts slutning fra Erstatningslovkomiteens innstilling fra 1971 trekker riktignok i annen retning. Fra denne slutter førstvoterende at den skadelidte "skulle gis mulighet for å disponere årlige beløp med samme kjøpekraft som det nominelle årlige tap det ble tatt utgangspunkt i". ${ }^{55}$ Hvis den erstatningsberettigede skal kunne disponere årlige beløp med samme kjøpekraft som det nominelle årlige tap, forutsetter dette at kapitaliseringsrenten gir full inflasjonsbeskyttelse. Det må dermed legges en realrente til grunn for kapitaliseringsrenten. Hylland har uttalt at denne uttalelsen fra Høyesterett vitner om en "klar og prinsipiell tilslutning til valorisme". ${ }^{56}$

Med henvisning til slutningen fra erstatningslovkomiteen slår Høyesterett videre fast at det ved fastsettelsen av kapitaliseringsrenten "må tas hensyn til muligheten for verdisikring". ${ }^{57}$ Hva som ligger i ordet "verdisikring" har Høyesterett akkurat forklart. Den skal gi skadelidte en "rimelig mulighet til å beskytte seg mot fall i pengeverdien". Men bruken av ordet kan også tyde på at Høyesterett mener at den erstatningsberettigede har muligheten til å sikre seg mot fall i pengeverdien, og at det må tas hensyn til dette ved fastsettelsen av kapitaliseringsrenten. Sett i sammenheng med at Høyesterett ikke gir sin fulle tilslutning til bruken av ordet realrente, kan dette indikere at avgjørelsen kan tas til inntekt for at den erstatningsberettigede bare skulle gis delvis kompensasjon for fall i pengeverdien.

Det fremstår dermed som uklart hvorvidt Høyesterett mener kapitaliseringsrenten skal gi full inflasjonsbeskyttelse. Eide og Hylland er derimot enige om at premissene som det er referert til viser at Høyesterett i begrunnelsen ønsker å legge det valoriske prinsipp til grunn for

\footnotetext{
${ }^{54}$ På side 1533 .

${ }^{55}$ På side 1532 .

${ }^{56}$ Hylland 1995 på side 49.

${ }^{57}$ På side 1532.
} 
fastsettelsen av kapitaliseringsrenten. ${ }^{58}$ Eide hevder riktignok at Høyesterett ikke følger opp dette ved valg av rentefotens størrelse. ${ }^{59}$ Begrunnelsen for dette er at Høyesterett avslutningsvis i premissene viser til de sakkyndiges vurderinger om at rentenivået de påfølgende årene vil bli noe lavere enn tidligere år. Høyesterett fant det derfor riktig "å bruke en noe lavere kapitaliseringsrente enn den som i de senere år er brukt i praksis". ${ }^{60}$ Resultatet ble en kapitaliseringsrente på $5 \%$. Eide hevder at kapitaliseringsrenten "som de senere årene hadde blitt brukt i praksis", måtte være rentefoten som ble valgt i Sevaldsen-dommen. Som nevnt ovenfor ble det her benyttet en rentefot på $6 \%$, og Høyesterett ga klart uttrykk for at det ikke skulle gis inflasjonskompensasjon ved fastsettelsen av rentefotens størrelse. Når Høyesterett nå bestemmer seg for å gi en rimelig beskyttelse mot inflasjon, samtidig som at Høyesterett viser til at rentenivået i fremtiden vil være noe lavere enn tidligere, mener Eide det fremstår som betenkelig at renten bare settes ned med $1 \%$. Eide hevder dermed at dommen rent faktisk la til grunn det nominalistiske prinsipp.

En siste avgjørelse som kort skal nevnes er Flåmyra-kjennelsen. Saken gjaldt fastsettelse av kapitaliseringsrente ved erstatning for bruksverdi etter fredning av skog. I tilknytning til dette spørsmålet uttaler førstvoterende følgende: ${ }^{61}$

"Som nevnt, er det slik jeg ser det, særlig hensynet til at man har hatt og fortsatt vil ha behov for de avståtte ytelser på det tidspunkt de ville ha vært oppebåret dersom avståelsen ikke var skjedd, som kan begrunne en særlig inflasjonsbeskyttelse. Hvis man foretar en mer generell vurdering av skogbruket, gjør dette hensyn seg iallfall ikke sterkere gjeldende her enn ved personskadeerstatninger."

Uttalelsen indikerer at det ikke nødvendigvis er grunnlag for den samme inflasjonsbeskyttelse ved utmåling av bruksverdierstatning for skog som ved utmåling av fremtidig inntektstap på personskadeerstatningsrettens område. At førstvoterende mener det skal være en forskjell mellom de to rettsområdene understøttes av en uttalelse senere i saken. I tilknytning til valg av rentefot uttaler førstvoterende at "en objektivisert kapitaliseringsrente for skog bør ikke ligge lavere enn denne rentefoten, jf. det jeg har sagt om de hensyn som gjør seg gjeldende". ${ }^{62}$ Rentefoten det henvises til er den som ble benyttet i Ølberg-dommen. Begrunnelsen førstvoterende anfører for at det skal være en forskjell mellom de to rettsområdene, er vanskelig å forstå.

\footnotetext{
${ }^{58}$ Hylland 1995 på side 49 og Eide 2011 på side 147.

${ }^{59}$ Eide 2011 på side 148.

${ }^{60}$ På side 1533 og side 1534.

${ }^{61}$ Rt. 1994 s. 557 på side 562.

${ }^{62}$ Rt. 1994 s. 557 på side 563.
} 
Oppsummert kan det dermed sies at det er noe uklart om Høyesterett i avgjørelsene før Kreutzer-dommen fullt ut forlot det nominalistiske prinsipp. Dette kan begrunnes i flere forhold. For det første at Høyesterett vegret seg med å benytte begrepet realrente, som er den rente som må legges til grunn for at det valoriske prinsipp kan anses å gjelde. For det annet fremstår premissene i flere av avgjørelsene som uklare, ved at den skadelidte bare skal gis "rimelig" beskyttelse mot inflasjon, og at verdisikringshensyn skal tas i betraktning ved fastsettelsen av rentefotens størrelse. Selv om premissene i Ølberg-dommen trekker i retning av at det valoriske prinsipp skal gjelde ved fastsettelse av rentefoten, gjenspeiler ikke dette seg i valg av en rentefot på $5 \%$. Uttalelsene i Flåmyra-kjennelsen kan tilsi at Høyesterett mener at det ikke skal gis samme inflasjonsbeskyttelse på ekspropriasjonsrettens område som på personskadeerstatningsrettens område. I det følgende vil kritikken fra teorien bli gjennomgått for å illustrere hvilket prinsipp som må legges til grunn for at den erstatningsberettigede skal få full erstatning.

\subsection{Kritikken i kjølvannet av rettspraksis før Kreutzer-dommen}

Avgjørelsene som er analysert ovenfor, har vært gjenstand for kritikk fra teoretisk hold. De to mest fremtredende kritikerne har vært Erling Eide og Aanund Hylland. Kritikken har rettet seg mot Høyesteretts vurdering av hvilke elementer som skal legges til grunn for kapitaliseringsrenten og rentefotens størrelse. Det er blitt hevdet at kapitaliseringsrenten ikke gir skadelidte krav om full erstatning.

Som vist har Høyesterett vegret seg mot å benytte begrepet "realrente". I Noem-dommen ble dette begrunnet med at begrepet ikke var entydig ved at det ble brukt i forskjellig betydning $\mathrm{i}$ forskjellige saker. Dokumentasjonen som ble lagt frem for Høyesterett i samme sak viste også realrenten til tider hadde vært negativ, noe som det i følge Høyesterett ikke kan opereres med i erstatningssammenheng. Som uttalt av Eide og Hylland medfører disse uttalelsene ikke riktighet. Selv om realrenten varierer og er avhengig av skiftende faktorer, er selve begrepet entydig. ${ }^{63}$ Realrenten er differansen mellom den nominelle renten og forventet prisstigning. Ved å benytte realrenten ved kapitaliseringen vil den erstatningsberettigede få erstattet realverdien av sitt tap. Rett nok vil realrenten variere avhengig av risikoen ved ulike investeringsalternativer. Denne variasjonen vil også finnes i den nominelle renten for ulike investeringsalternativer.

\footnotetext{
${ }^{63}$ Hylland 1995 på side 47 og Eide 2011 på side 144.
} 
Eide og Hylland kritiserer også Høyesterett for ikke å begrunne hvorfor det ikke kan opereres med en negativ realrente i erstatningssammenheng. ${ }^{64}$ For det første vil det være helt nødvendig å benytte en negativ realrente hvis inflasjonen er prosentvis større enn den nominelle renten. For det annet er det uproblematisk rent matematisk å benytte en negativ rentefot ved kapitaliseringen. Eksempelet som Eide benytter illustrerer dette. ${ }^{65}$ Man kan tenke seg at en erstatningsberettiget vil lide et tap i år 1 på 100. Hvis den nominelle renten er $3 \%$ og den forventede prisstigning er på $5 \%$ vil realrenten være $-2 \%$. Regnestykket blir dermed slik: $100 \mathrm{x}(1,05 / 1,03)=$ ca. 102 . Dette innebærer at den erstatningsberettigede må få utbetalt 102 kroner i år 0 for at den skal kunne disponere et beløp med tilsvarende kjøpekraft som året tapet vil oppstå.

Kjernen i kritikken som har vært rettet mot Høyesterett, er at en avvisning av å legge en realrente til grunn for kapitaliseringen ikke vil gi den erstatningsberettigede full erstatning. Som vist ovenfor er det riktignok skjedd en utvikling i rettspraksis fra det nominalistiske til det valoriske prinsipp ved fastsettelsen av kapitaliseringsrenten. Men premissene i avgjørelsene har fremstått som uklare, og rentefotens størrelse, samt begrunnelsen for den, kan tyde på at den erstatningsberettigede ikke har fått full inflasjonsbeskyttelse ved kapitaliseringen. Både Hylland og Eide hevder at den erstatningsberettigede ikke får full erstatning som følge av dette. ${ }^{66}$

Når en inntektsstrøm skal diskonteres gjelder følgende prinsipp: hvis inntekten oppgis i nominelle (løpende) priser, skal nominell rente benyttes. Hvis inntekten oppgis i faste (inflasjonskorrigerte) priser, skal realrente benyttes. Hvilken av de to metodene som benyttes er uten betydning, da resultatet vil bli det samme. Dette kan vises med følgende eksempler:

En erstatningsberettiget vil lide et tap på 100000 kroner per år ti år frem i tid regnet etter dagens priser. Den nominelle renten er $5 \%$ og den forventede prisstigningen per år $3 \%$. Hvis tapet oppgis i nominelle priser og den nominelle renten benyttes ved kapitaliseringen vil regnestykket bli som følger:

$134391 / 1,05^{10}+130477 / 1,05^{9}+126677 / 1,05^{8}+122987 / 1,05^{7}+119405 / 1,05^{6}+$ $115927 / 1,05^{5}+112550 / 1,05^{4}+109272 / 1,05^{3}+106090 / 1,05^{2}+103000 / 1,05=$ ca. 900000

Den erstatningsberettigede skal i dette tilfelle ha utbetalt ca. 900000 kroner i år 0 .

\footnotetext{
${ }^{64}$ Hylland 1995 på side 47 og Eide 2011 på side 144.

${ }^{65}$ Eide 2011 på side 144.

${ }^{66}$ Hylland 1995 side 54 og Eide 2011 side 125.
} 
Hvis de årlige tapene oppgis i faste priser og realrenten legges til grunn for kapitaliseringen, vil regnestykket bli som følger:

$$
\begin{aligned}
& 100000 \times\left(1 / 1,02+1 / 1,02^{2}+1 / 1,02^{3}+1 / 1,02^{4}+1 / 1,02^{5}+1 / 1,02^{6}+1 / 1,02^{7}+1 / 1,02^{8}+\right. \\
& \left.1 / 1,02^{9}+1 / 1,02^{10}\right)=\text { ca. } 900000
\end{aligned}
$$

Den erstatningsberettigede skal også her få utbetalt ca. 900000 kroner. Utregningen viser at den erstatningsberettigede vil få utbetalt det samme beløpet uavhengig av om erstatningen beregnes etter løpende priser og kapitaliseres med nominell rente, eller ved faste priser kapitalisert med en realrente.

I norsk rett er det tradisjon for at erstatning for tap frem i tid fastsettes etter faste priser. Når det benyttes faste priser for å utmåle de årlige tapene frem i tid, skjer dette i visshet om at disse beløpene ikke vil gjenspeile det faktiske årlige tapet i inflasjonstider. Hvis det da benyttes en nominell rente ved kapitaliseringen, vil den erstatningsberettigede ikke få full erstatning. Dette kan illustreres ved å kapitalisere de faste prisene med den nominelle rentefoten. Regnestykket blir da som følger:

$$
\begin{aligned}
& 100000 \times\left(1 / 1,05+1 / 1,05^{2}+1 / 1,05^{3}+1 / 1,05^{4}+1 / 1,05^{5}+1 / 1,05^{6}+1 / 1,05^{7}+1 / 1,05^{8}+\right. \\
& \left.1 / 1,05^{9}+1 / 1,05^{10}\right)=\text { ca. } 772000
\end{aligned}
$$

Den erstatningsberettigede vil i dette tilfelle ikke få utbetalt mer enn 772000 kroner. Hvis den erstatningsberettigede plasserer erstatningsbeløpet på en slik måte at det gir en avkastning på $5 \%$, vil den erstatningsberettigede kunne disponere et årlig beløp på 100000 kroner. Ved inflasjon vil tapet endre seg i henhold til konsumprisindeksen for hvert år. De årlige tapene vil dermed gradvis bli større. Hvis man skal følge det korrekte utgangspunktet i Ølbergdommen ${ }^{67}$ om at en må "finne frem til den rente som, dersom nåtidsverdien investeres til denne renten, gjør det mulig for skadelidte å ta ut et beløp tilsvarende det årlige tapet i hvert av de årene tapene oppstår", forutsetter dette at det benyttes en realrente ved kapitaliseringen. Som påpekt av Eide, viser dette at man ved kapitaliseringen av erstatningsbeløpet ikke kan legge vekt på verdisikringshensyn slik Høyesterett ser ut til å gjøre i Noem-dommen og Ølberg-dommen. ${ }^{68}$ Det er riktig at den erstatningsberettigede vil få muligheten til å verdisikre erstatningsbeløpet. Men som Eide påpeker vil den nominelle avkastning bare sikre "realverdien av den beregnede nåverdien av tapene og kan ikke avhjelpe problemet med at

\footnotetext{
${ }^{67}$ Rt. 1993 s. 1524 på side 1530.

${ }^{68}$ Eide 2011 på side 134.
} 
dette beløpet eventuelt er galt beregnet (kapitalisert ved anvendelse av en nominell rente)". ${ }^{69}$ Eide forklarer denne feilen som "Høyesteretts misforståelse".

Konklusjonen er dermed at en realrente må legges til grunn for at den erstatningsberettigede skal gis full erstatning. Spørsmålet er så om Høyesterett har tatt høyde for dette i den nylig avsagte Kreutzer-dommen.

\subsection{Høyesteretts vurdering av inflasjonskompensasjon i Kreutzer-dommen}

Med henvisning til skadeserstatningsloven § 3-1, slår Høyesterett fast innledningsvis i dommen at den skadelidte har krav på full erstatning, verken mer eller mindre. ${ }^{70}$ Videre slås det fast at inntektene som fulgte av Norges Juristforbunds statistikker og som skal legges til grunn for erstatningsutmålingen, vil komme til å bli høyere som følge av inflasjonen. Deretter uttaler førstvoterende følgende: ${ }^{71}$

"Skal det tas høyde for inflasjonen, må dette gjøres gjennom den kapitaliseringsrenten som er utgangspunktet for diskontering av tapt fremtidig inntekt ned til en nåtidsverdi:

Kapitaliseringsrenten må baseres på en realrente, altså enkelt sagt antatt nominell rente i erstatningsperioden minus forventet inflasjonsrate i samme periode."

Det siterte levner ingen tvil om at den kapitaliseringsrenten som skal benyttes må gi full kompensasjon for forventet fremtidig inflasjon. I motsetning til tidligere avgjørelser anerkjenner Høyesterett bruken av begrepet realrente. Definisjonen av begrepet er også korrekt, jamfør definisjonen i punkt 1.4.2 ovenfor.

Høyesterett hevder at det følger av Noem-dommen at det "må tas hensyn til inflasjonen". ${ }^{72}$ Dette medfører riktighet så lenge "hensyn til inflasjonen" leses som at det ikke skal gis full inflasjon, men at det skal gis en viss inflasjonskompensasjon. Førstvoterende fortsetter og slutter fra Ølberg-dommen at det "klart ble slått fast at kapitaliseringsrenten skal være en realrente". ${ }^{73}$ Som vist ovenfor fremstår dette ikke som helt klart. Høyesterett vegret seg for å benytte begrepet. Men selv om begrunnelsen i dommen nærmet seg en definisjon av

\footnotetext{
${ }^{69}$ Eide 2011 på side 134.

${ }^{70}$ Rt. 2014 s. 1203 avsnitt 71.

${ }^{71}$ Avsnitt 74.

${ }^{72}$ Avsnitt 75.

${ }^{73}$ Avsnitt 75.
} 
realrentebegrepet, så er dommen kritisert for at rentefotens størrelse var for høy til å anses som en realrente. ${ }^{74}$

Avslutningsvis for spørsmålet om inflasjonskompensasjon slår Høyesterett fast at realverdien av de årlige tapene må kompenseres for at skadelidte ikke skal komme dårligere ut enn om skaden ikke hadde inntruffet. ${ }^{75}$ Dette innebærer at erstatningsbeløpet må kapitaliseres med en realrente.

Selv om Høyesterett ikke sier seg enig i kritikken av tidligere rettspraksis, må feilen nå anses rettet opp. Det er nå ikke lenger tvilsomt at det skal legges en realrente til grunn for kapitaliseringen.

Konklusjonen er dermed at Høyesteretts standpunkt til spørsmålet om inflasjonskompensasjon ved fastsettelsen av kapitaliseringsrenten gir skadelidte krav på full erstatning.

\subsection{Nominell rente og realrente på ekspropriasjonsrettens område}

Spørsmålet er så om Kreutzer-dommen innebærer at det også skal legges til grunn en realrente ved kapitaliseringen av bruksverdierstatning på ekspropriasjonsrettens område. Som vist under punkt 4.2 indikerer Høyesterett i Flåmyra-kjennelsen at behovet for inflasjonsbeskyttelse ikke nødvendigvis er like påtrengende ved utmåling av bruksverdierstatning for skog. Høyesterett har imidlertid etter denne kjennelsen konsekvent lagt til grunn den samme kapitaliseringsrenten som ble fastsatt i Ølberg-dommen, også på ekspropriasjonsrettens område. Når Høyesterett i Kreutzer-dommen mener at Ølberg-dommen klart ga uttrykk for at det skal benyttes en realrente ved kapitaliseringen, innebærer dette at Høyesterett nå mener det er blitt benyttet en realrente i årene etter Ølberg-dommen. Sammenholder man dette med at Høyesterett i Kreutzer-dommen knytter behovet for å benytte en realrente tett opp mot kravet om full erstatning, må dette innebære at kapitaliseringsrenten som skal benyttes på ekspropriasjonsrettens område også skal være en realrente. Høyesterett kan umulig mene at kravet om full erstatning i denne sammenheng er forskjellig på de to rettsområdene.

Konklusjonen må dermed være at en realrente skal legges til grunn for kapitaliseringsrenten også på ekspropriasjonsrettens område.

\footnotetext{
${ }^{74}$ Hylland 1995 på side 54 og Eide 2011 på side 149.

${ }^{75}$ Avsnitt 77.
} 


\section{Kompensasjon for forventet reallønnsvekst}

\subsection{Innledning}

Som følge av den alminnelige velstandsutviklingen vil det kunne finne sted en reallønnsvekst. Med reallønnsvekst forstås differansen mellom den nominelle lønnsveksten og inflasjon. Spørsmålet om forventet reallønnsvekst betydning ved utmåling av erstatning for fremtidige inntektstap, har vært gjenstand for lite behandling i norsk rett. Før spørsmålet ble reist i Kreutzer-dommen har det ved få anledninger blitt vurdert av Høyesterett. Her skal nevnes Rt. 1993 s. 1538 Horseng-dommen. Spørsmålet er også i noen grad berørt i Erstatningslovkomiteens utredning (1971), NOU 1994:20 og NOU 2011:16.

Hvis det skal tas hensyn til reallønnsvekst ved utmåling av erstatning for fremtidig inntektstap, kan dette potensielt gjøres på to måter. Det kan for det første gjøres ved et tillegg $i$ de årlige fremtidige tapene. Alternativt, hvis tapene er beregnet etter dagens priser, kan det gjøres et fradrag i renten som benyttes for å kapitalisere tapene. I norsk rett er det som nevnt praksis for at de årlige tapene fastsettes etter faste priser. De sakkyndige i Kreutzer-dommen mente derfor at det som følge av forventet reallønnsvekst i fremtiden skulle gjøres et fradrag i kapitaliseringsrenten. Dette ville i så fall ført til en høyere erstatning for skadelidte, da hun skulle kompenseres for den forventede reallønnsveksten.

I det følgende vil det først vurderes om gjeldende rett før Kreutzer-dommen ga grunnlag for å ta høyde for forventet reallønnsvekst ved fastsettelsen av kapitaliseringsrenten. Videre vil det foretas en analyse og vurdering av Kreutzer-dommens standpunkt til dette spørsmålet. Avslutningsvis vurderes det om kravet om full erstatning tilsier at kapitaliseringsrenten bør inneholde en komponent som tar høyde for forventet reallønnsvekst.

\subsection{Gjeldende rett før Kreutzer-dommen}

Horseng-dommen ${ }^{76}$ gjaldt erstatningsoppgjøret ved personskade. En kvinne hadde blitt påkjørt av en bil og var som følge av dette blitt varig ufør. Et av spørsmålene i saken var hvorvidt de årlige tapene skulle økes som følge av en forventet reallønnsvekst. Lagmannsretten hadde tidligere i saksgangen slått fast at det måtte tas hensyn til forventet reallønnsvekst ved erstatningsutmålingen. Skadelidte hevdet at det måtte gjøres et påslag i inntektsanslaget med 10000 kroner per år, noe forsikringsselskapet var uenig i.

\footnotetext{
${ }^{76}$ Rt. 1993 s. 1538.
} 
I tilknytning til dette spørsmålet henviser førstvoterende til uttalelser fra

Erstatningslovkomiteens utredning av 1971. Det sluttes fra denne at komiteen ga uttrykk for "at verdisikringen bør knyttes til fallet i pengeverdi, men at man ikke bør ta sikte på en regulering som gir skadelidte andel i den alminnelige velstandsutviklingen" ${ }^{77}$ Førstvoterende finner imidlertid ikke grunn til å ta standpunkt til det prinsipielle spørsmålet om forventet reallønnsvekst betydning for erstatningsutmålingen. Begrunnelsen var at tillegget i den konkrete saken uansett ville blitt så lite at det ikke ville ha praktisk betydning for totalvurderingen. Dommen kan dermed ikke forstås som en avvisning av å ta forventet reallønnsvekst i betraktning ved utmålingen av tap i fremtidig inntekt.

I NOU 1994:20 på side 150 slår utvalget fast at det etter gjeldende rett ikke er avgjort om det skal tas hensyn til reallønnsvekst. Utvalget konkluderer ikke på hvorvidt dette bør gjøres eller ikke, men nevner at det ikke er noe i veien for at det tas hensyn til alminnelig velstandsutvikling. Det samme legges til grunn i NOU 2011:16 (på side 92).

Spørsmålet er blitt lite belyst i teorien, men de fleste teoretikere på området åpner for at det ikke er noe i veien for at det ved erstatningsutmålingen tas høyde for forventet reallønnsvekst. ${ }^{78}$ Lødrup hevder at det er "lite tvilsomt at uttalelsene i forarbeidene ikke fortjener tilslutning". ${ }^{79}$ Forarbeidene det siktes til er Erstatningslovkomiteens innstilling (1971) hvor det fremgår at skadelidte ikke skal ha noen andel av den alminnelige velstandsutviklingen ved utmålingen av fremtidig tap.

Før Kreutzer-dommen finnes det ingen rettskilder som utelukker at det kan tas høyde for reallønnsveksten. Forarbeidene åpner for det, men domstolene har ikke tatt stilling til det prinsipielle spørsmålet om dette bør gjøres.

\subsection{Høyesteretts vurdering i Kreutzer-dommen}

For tingretten og lagmannsretten hadde partene i Kreutzer-saken ikke prosedert på at det ved fastsettelsen av kapitaliseringsrenten måtte tas hensyn til forventet reallønnsvekst. Spørsmålet kom først inn i saken etter at de tre sakkyndige i sin erklæring slo fast at dette var nødvendig for å sikre skadelidte full erstatning. Med støtte i fremtidsprognoser fra OECD og SSB la de sakkyndige til grunn at det ville finne sted en generell reallønnsvekst $\mathrm{i}$ tidshorisonten for inntektsstrømmen som skulle erstattes. Reallønnsveksten ble lagt inn som et fradrag fra

\footnotetext{
${ }^{77}$ Rt. 1993 s. 1538 på side 1543.

${ }^{78}$ For eksempel Syse m. fl. 2011 på side 373, Lødrup m. fl. 2009 på side 489 og Nygaard 2007 på side 94.

${ }^{79}$ Lødrup m. fl. 2009 på side 490.
} 
realrenten ved beregningen av kapitaliseringsrenten. De sakkyndige anslo reallønnsveksten til å utgjøre 1,25 til 1,5\% per år.

Innledningsvis i tilknytning til dette spørsmålet slår førstvoterende fast at hvis det skulle vært aktuelt å ta hensyn til eventuell reallønnsvekst knyttet til erstatningsutmålingen, må dette skje ved fastsettelsen av de årlige tapene. ${ }^{80}$

Hvorfor forventet reallønnsvekst ikke bør trekkes inn ved fastsettelsen av kapitaliseringsrenten, begrunnes ikke av førstvoterende. En mulig begrunnelse kan være at det er nettotapet i de ulike årene som skal erstattes. Dette innebærer at det skal gjøres et fradrag for utgiftene knyttet til opparbeidelsen av inntekten. Da reallønnsveksten kun knytter seg til bruttoinntekten, ikke til utgiftene, vil det være en enklere $\varnothing$ velse å gjøre et tillegg for reallønnsvekst ved fastsettelse av inntektsstrømmen i kronebeløp. Alternativt må man operere med to forskjellige kapitaliseringsrenter, en for inntekter og en for utgifter. Sistnevnte løsning fremstår som noe tungvint.

I samme avsnitt understreker førstvoterende at man ved vurderingen av fremtidig inntektstap ofte må nøye seg med "nokså usikre og forenklede anslag", at partenes standpunkter lett vil kunne få et "preg av forhandlingsutspill" og at resultatet "vil kunne bli noe av et kompromiss". Denne usikkerheten blir spesielt begrunnet i tvil rundt fastsettelsen av det hypotetiske yrkesvalget, og den store graden av skjønn dette medfører fra domstolenes side hvis partene ikke kommer til enighet. Dette sammenholdt med at det ikke var tatt hensyn til ulike utgiftsposter knyttet til det å ta utdannelse og stå i arbeid, gjør at førstvoterende slår fast at det dermed ikke kan "ha vært partenes forutsetning at det skulle kunne trekkes inn ytterligere generelle inntekts- eller tapsposter". ${ }^{81}$ Når spørsmålet ikke har vært trukket inn som en selvstendig faktor i diskusjonene mellom partene, og heller ikke tatt stilling til i tidligere instanser, mener Høyesterett at det blir feil å trekke inn dette ved fastsettelsen av kapitaliseringsrenten i denne saken.

Høyesterett trekker dermed frem et generelt argument og et konkret argument mot at det ved erstatningsutmålingen skal ta hensyn til reallønnsveksten. Det generelle argumentet, som nok også vil kunne gjøres gjeldende i senere saker, er at det allerede knytter seg stor usikkerhet knyttet til nøyaktigheten av de årlige tapene. Førstvoterende må dermed mene det blir feil å legge til et element det er knyttet usikkerhet til, forventet reallønnsvekst, på et allerede

\footnotetext{
${ }^{80}$ Rt. 2014 s. 1203 avsnitt 79.

${ }^{81}$ Avsnitt 80.
} 
usikkert utmålt tap. Det konkrete argumentet, som nok ikke vil gjøre seg gjeldende i senere saker, er at partene ikke tidligere i saksgangen har diskutert spørsmålet.

Endelig slår førstvoterende fast at det ikke tas stilling til om "det ved personskadeerstatning for fremtidige inntektstap generelt sett er adgang til å kreve kompensasjon for reallønnsvekst". Begrunnelsen for dette er at spørsmålet er blitt reist av de sakkyndige og at det dermed ikke hadde blitt prosedert og belyst av partene.

Som uttalt av førstvoterende kan det se ut som at det er lite sannsynlig at usikkerhet knyttet til realverdien av beløpet vil kunne ha betydning for kapitaliseringsrenten. Alternativet som står igjen er at forventet reallønnsvekst gjør seg utslag i kronebeløpene som legges til grunn for de årlige tapene. Høyesterett avviste en slik fremgangsmåte i denne saken, men vegret seg fra å ta stilling til spørsmålet om muligheten for at dette gjøres i senere saker.

Det kan likevel reises spørsmål om vurderingene som foretas i avgjørelsen vil kunne få større rekkevidde enn Høyesterett selv ønsker å gi uttrykk for. For det første fremsetter førstvoterende et generelt utformet argument som gir uttrykk for en avvisende holdning til spørsmålet om det skal tas hensyn til usikkerhet knyttet til realverdien av tapene ved utmålingen av personskadeerstatning for fremtidig inntektstap. Senere i avgjørelsen legger også førstvoterende vekt på hensynet til stabilitet i forhold til den renten som legges til grunn i dommen. Det uttales at det likevel er av betydning "at det ville komplisere og fordyre erstatningsoppgjørene dersom den generelle kapitaliseringsrenten til stadighet skulle justeres av domstolene". ${ }^{82}$ Høyesterett er dermed innforstått med at rentenivået som legges til grunn vil fremstå som et prejudikat også for senere saker. Det må dermed anses som lite sannsynlig at Høyesterett vil vurdere kapitaliseringsrenten på nytt i nær fremtid, uavhengig av om spørsmålet om forventet reallønnsvekst har vært gjenstand for forhandling mellom partene.

Konklusjonen må dermed være at selv om Høyesterett ikke ønsket å ta stilling til om det ved utmålingen av erstatning for fremtidig inntekt skal tas hensyn til reallønnsveksten, er det flere forhold som tilsier at dette heller ikke vil skje i senere saker.

\footnotetext{
${ }^{82}$ Avsnitt 99.
} 


\subsection{Reallønnsvekst og kravet om full erstatning}

Under dette punkt skal det vurderes om kravet om full erstatning tilsier at det tas høyde for reallønnsveksten ved fastsettelsen av kapitaliseringsrenten. Kravet om full erstatning innebærer at den erstatningsberettigede skal stilles i samme $\varnothing$ konomiske situasjon som tilfellet ville vært hvis skaden eller ekspropriasjonen ikke hadde funnet sted.

Hvis det er sannsynlig at det vil finne sted en reallønnsvekst, vil det å se bort fra dette innebære at den erstatningsberettigede stilles i en dårligere økonomisk situasjon enn tilfellet hadde vært hvis skaden eller ekspropriasjonen ikke hadde funnet sted. Dette kan illustreres med et eksempel: En skadelidt vil lide et tap på 100000 kroner regnet etter dagens priser i ti år frem i tid. Det legges til grunn en realrente på $4 \%$ og en forventet reallønnsvekst på 1,5\%. Hvis det ikke tas høyde for forventet reallønnsvekst vil den skadelidte få utbetalt ca. 811000 kroner. Hvis det derimot tas høyde for forventet reallønnsvekst, vil tapet kapitaliseres med en kapitaliseringsrente lik 2,5\%. Den skadelidte vil da få utbetalt 875000 kroner. Regnestykket viser at den skadelidte vil få utbetalt ca. 64000 kroner mer hvis det tas hensyn til reallønnsveksten ved kapitaliseringen.

Det generelle argumentet Høyesterett trekker frem i Kreutzer-dommen, er at fastsettelsen av det fremtidige inntektstap ofte beror på usikre og forenklede anslag. Høyesterett understreker at dette gjelder spesielt i tilfellene hvor det er "uklart hva slags yrkeskarriere den skadelidte ville hatt uten skaden", da partenes standpunkter ofte vil ha karakter av forhandlingsutspill, og det "endelige resultatet vil kunne bli noe av et kompromiss". ${ }^{83}$ Denne usikkerheten kan gå i begge retninger. Den skadelidte vil kunne risikere at det både legges til grunn en for lav og for høy erstatningssum sammenlignet med hva som ville vært tilfelle hvis skaden tenkes borte. Hvis partene er uenige om dette spørsmålet er domstolene henvist til å fastlegge skadelidtes hypotetiske livssituasjon. På erstatningsrettens område gjelder prinsippet om sannsynlighetsovervekt. Dette innebærer at det mest sannsynlige skal legges til grunn. Hvis det er sannsynlighetsovervekt for at det vil finne sted en reallønnsvekst, bør dette legges til grunn for erstatningsutmålingen.

Ser man på hvor få tilfeller hvor spørsmålet om reallønnsvekst har vært oppe for Høyesterett, kan det likevel stilles spørsmålstegn ved hvor aktuelt det egentlig er å ta hensyn til forventet reallønnsvekst ved erstatningsutmålingen. Mye kan derfor tyde på at domstolene med rette legger vekt på at fastsettelsen av inntektstapet ofte er et resultat av et kompromiss, eller at domstolenes anslag i stor grad er basert på skjønn. Uavhengig av dette bør forventet

\footnotetext{
${ }^{83}$ Avsnitt 79.
} 
reallønnsvekst ikke trekkes inn ved fastsettelsen av kapitaliseringsrenten. Hvis så er tilfelle vil man måtte benytte forskjellige kapitaliseringsrenter for inntekter og utgifter, da reallønnsveksten kun knytter seg til inntektssiden.

Konklusjonen må dermed være at kravet om full erstatning tilsier at det tas hensyn til reallønnsvekst ved utmålingen av erstatningen. Skal det tas hensyn til reallønnsvekst bør dette gjøres ved fastsettelsen av den fremtidige inntektsstrømmen.

\subsection{Reallønnsvekst på ekspropriasjonsrettens område}

Det kan tenkes at en alminnelig velstandsøkning også kan medføre en økning i skog- og jordbrukeres kapitalinntekt. Hvis dette er tilfelle tilsier kravet om full erstatning av det bør tas hensyn til den fremtidige reallønnsveksten ved utmålingen av bruksverdierstatning ved ekspropriasjon. Ved fastsettelsen av de årlige nettotapene vil vurderingen av sparte kostnader muligens stå enda mer sentralt enn tilfellet er ved utmåling av fremtidig inntektstap på personskadeerstatningsrettens område. Skog- og jordbrukere vil normalt ha større kostnader knyttet til inntjeningen enn tilfellet er for en vanlig arbeidstaker. Dette tilsier at det på ekspropriasjonsrettens område er enda mindre aktuelt å ta hensyn til forventet reallønnsvekst ved fastsettelsen av kapitaliseringsrenten.

\section{Inntektsusikkerhet og aktuarisk risiko}

\subsection{Innledning}

Ved utmåling av erstatning for inntekter som forventes oppstått frem i tid, knytter det seg alltid en viss usikkerhet. En bonde vil for eksempel som følge av tørke oppleve dårlige avlinger fra tid til annen, og en arbeidstaker kan av forskjellige årsaker blitt ufør. Graden av usikkerhet vil variere i forhold til sannsynligheten for at den forventede inntekt ikke vil oppstå.

Hvis det skal tas hensyn til usikkerheten kan dette potensielt gjøres på to måter. For det første kan det gjøres ved et fradrag i den tapte inntektsstrømmen. Alternativt kan det gjøres ved å legge til en usikkerhetskomponent i kapitaliseringsrenten.

I Kreutzer-saken ble spørsmålet om risikoenes betydning for erstatningsutmålingen først reist av de sakkyndige for Høyesterett. De mente at det ville være en risiko for at den skadelidte ikke fullfører det utdanningsløpet som eventuelt legges til grunn, eller fullfører, men ikke får jobb innenfor det yrke som legges til grunn av domstolen. Denne type risiko ble av de 
sakkyndige i Kreutzer-saken betegnet som aktuarisk risiko. ${ }^{84}$ De sakkyndige mente denne usikkerheten måtte gjenspeile seg i et tillegg på 0,75 \% i kapitaliseringsrenten. Videre mente de sakkyndige at det knyttet seg usikkerhet til hvor i inntektsfordelingen den skadelidte faktisk ville havne. Denne usikkerheten ble betegnet som inntektsusikkerhet av de sakkyndige. Det ble foreslått at også denne usikkerhetskomponenten burde gjenspeile seg i et tillegg på $0,75 \%$.

Tilleggene medfører at disse usikkerhetene må bæres av den skadelidte, og erstatningsbeløpet vil følgelig bli lavere. Partene i saken var derimot enige om at kapitaliseringsrenten skulle fastsettes uten å ta hensyn til denne risikoen.

I det følgende vil det reises to problemstillinger. For det første om gjeldende rett gir grunnlag for å ta hensyn til usikkerheten knyttet til den tapte inntektsstrømmen ved fastsettelsen av kapitaliseringsrenten. For det annet vil det vurderes hvorvidt kravet om full erstatning tilsier at kapitaliseringsrenten bør inneholde en komponent som tar høyde for denne usikkerheten.

\subsection{Gjeldende rett}

Spørsmålet om usikkerhet knyttet til de fremtidige inntektene skal gjøre seg utslag ved fastsettelse av kapitaliseringsrenten, har vært gjenstand for lite behandling av Høyesterett. Her skal nevnes Flåmyra-kjennelsen inntatt i Rt-1994-557. Kjennelsen gjaldt spørsmålet om kapitalisering av erstatning for bruksverdi etter fredning av skog. Overskjønnet hadde fastsatt en kapitaliseringsrente på $4 \%$. Staten anket overskjønnet, og mente rentefoten var satt for lavt. Ankemotparten hevdet at en kapitaliseringsrente på $4 \%$ var riktig, da dette gjenspeilte seg i det lave risikonivået i skogbruksnæringen.

Under behandlingen av saken hadde det blitt reist spørsmål ved hvorvidt Noem-dommen kunne tas til inntekt for at det ved fastsettelse av kapitaliseringsrenten burde tas hensyn til hvorvidt inntekten som skal erstattes er mer eller mindre sikker. Førstvoterende var ikke enig at spørsmålet var blitt drøftet i Noem-dommen, og han slår fast at denne usikkerheten ikke bør tas hensyn til ved fastsettelse av kapitaliseringsrenten. Begrunnelsen for dette var at når "man først har kommet frem til en sannsynlig årlig inntekt, har man i så fall tatt hensyn til en mulig usikkerhet". ${ }^{85}$

\footnotetext{
${ }^{84}$ Moen m. fl. 2014 side 4.

${ }^{85}$ Rt. 1994 s. 557 på side 561.
} 
I Kreutzer-dommen var begge partene som nevnt enige om at det ikke skulle tas hensyn til usikkerheten knyttet til den fremtidig tapte inntektsstrømmen. Det fremstår som merkelig at forsikringsselskapet ikke ønsket dette, da usikkerheten ville medføre en høyere kapitaliseringsrente, og dermed et lavere erstatningsbeløp.

Førstvoterende sier seg enig med partene $i$ at aktuarisk risiko og inntektsusikkerhet ikke skal spille inn ved fastsettelsen av kapitaliseringsrenten. ${ }^{86}$ Det anføres så to argumenter til støtte for denne konklusjonen. Det første argumentet er at aktuarisk risiko og inntektsusikkerhet vil variere mye fra skadetilfelle til skadetilfelle. Dette må sees i lys av Høyesteretts uttalte mål om at kapitaliseringsrenten skal være generell og ikke til stadighet justeres av domstolene, jamfør dommens avsnitt 99. Det andre argumentet er likt det som anføres i Flåmyrakjennelsen. Førstvoterende uttaler følgende:

"Selv om det nok fra et fagøkonomisk ståsted kan gi god mening å ta hensyn til dette som en slags forsikringspremie som er lik for alle ved beregning av kapitaliseringsrenten, er erstatningsretten basert på at man skal finne frem til den enkelte skadelidtes hypotetiske livsløp og inntekt på grunnlag av vanlige bevisregler. Er det - enkelt sagt - sannsynlighet for at den skadelidte for eksempel uansett ville ha blitt ufør i løpet av erstatningsperioden, tar man hensyn til dette når inntektstapet beregnes i kroner, ellers ikke."

Gjeldende rett innebærer dermed at usikkerhet knyttet til den fremtidige inntektsstrømmen ikke skal trekkes inn ved fastsettelsen av kapitaliseringsrenten. Den tapte inntektsstrømmen skal betraktes som sikker. Som det vil bli vist nedenfor under kapittel 8 , foreligger det en ubegrunnet inkonsistens mellom dette og risikoen som det forventes at skadelidte må bære ved plassering av erstatningsbeløpet.

\subsection{Risiko for manglende innfrielse og kravet om full erstatning.}

Kravet om full erstatning innebærer at den erstatningsberettigede skal stilles i samme $\emptyset$ konomiske situasjon som om skaden eller ekspropriasjonen ikke hadde funnet sted. Hvis den tapte inntektsstrømmen betraktes som sikker ved erstatningsutmålingen, innebærer dette at den skadelidte stilles i en bedre situasjon enn hvis skaden eller ekspropriasjonen ikke hadde funnet sted. Usikkerheten som var knyttet til inntektsstrømmen før skaden/ekspropriasjonen, skal ikke lenger bæres av den skadelidte eller ekspropriaten. Kravet om full erstatning som en $\emptyset$ konomisk størrelse tilsier dermed at det tas høyde for usikkerheten knyttet til den fremtidige inntektsstrømmen. Spørsmålet er så om argumentene Høyesterett trekker frem i avgjørelsene

\footnotetext{
${ }^{86}$ Avsnitt 83.
} 
nevnt i forrige punkt tilsier at det bør være en inkonsistens mellom kravet om full erstatning som henholdsvis et $\varnothing$ konomisk og juridisk begrep.

Ved tvil om hvilket faktum som skal legges til grunn, innebærer bevisregelen om "sannsynlighetsovervekt" at det mest sannsynlige skal legges til grunn. Er det for eksempel $60 \%$ sannsynlighet for at det foreligger årsakssammenheng mellom den skadevoldende handling og det $\varnothing$ konomiske tapet, legges det til grunn som sikkert at det foreligger årsakssammenheng. Usikkerheten, at det er $40 \%$ sannsynlighet for at det ikke foreligger årsakssammenheng, vil ikke gjøre seg utslag i et lavere erstatningsbeløp. Prinsippet om full erstatning, at skadelidte verken skal ha mer eller mindre enn det $\varnothing$ konomiske tap erstattet, gjelder på erstatningsrettens område generelt. Fra et juridisk perspektiv legges det dermed til grunn at kravet om full erstatning oppnås uten at usikkerheten gjør seg utslag i størrelsen av erstatningsbeløpet. Høyesterett sin løsning i de to ovennevnte dommene harmonerer godt med denne regelen, ved at usikkerhet knyttet til den forventede inntektsstrømmen ikke gjør seg utslag ved fastsettelsen av kapitaliseringsrenten. Hensynet til lik behandling av usikkerhet på erstatningsrettens område kan dermed tilsi at det ikke skal tas hensyn til denne usikkerheten ved fastsettelsen av kapitaliseringsrenten.

Hvis usikkerheten skulle gjøre seg utslag ved fastsettelsen av kapitaliseringsrenten, må usikkerheten kvantifiseres til en størrelse. Dette kan være en vanskelig øvelse. For det første knytter det seg mange usikkerhetsmomenter til den fremtidige inntektsstrømmen. Det er en usikkerhet for at den forventede inntekten ikke vil inntre, og at den vil kunne bli mindre enn forventet. Videre vil graden av usikkerhet kunne variere stort mellom forskjellige individer. Det vil for eksempel være knyttet større usikkerhet til den forventede inntektsstrømmen for en bonde som dyrker korn på en værutsatt plass, enn for en bonde som disponerer jord på en mer egnet lokasjon. Så lenge fastsettelsen av kapitaliseringsrenten er en domstolsoppgave, tilsier prosessøkonomiske hensyn at kapitaliseringsrenten ikke er gjenstand for vurdering i hver enkelt sak. Hensynet til enkelthet og at kapitaliseringsrenten må være generell, tilsier dermed at det ikke skal tas høyde for usikkerheten knyttet til inntektsstrømmen ved fastsettelsen av kapitaliseringsrenten.

Ved utmåling av bruksverdierstatning ved ekspropriasjon viser praksis fra skjønnsrettene at det har vært vanlig å behandle usikkerheten i tilknytning til fastsettelsen av kapitaliseringsrenten. Størrelsen på usikkerhetskomponenten var avhengig av risikoen tilknyttet den eksproprierte næringen. ${ }^{87}$ Et illustrerende eksempel, er overskjønnet som ble anket inn for Høyesterett i Noem-dommen. I overskjønnet var det benyttet en

\footnotetext{
${ }^{87}$ Stordrange m. fl. 2000.
} 
kapitaliseringsrente på 3,5\% for de eksproprierte skogarealene, og $6 \%$ for jordbruksarealene. Den eneste logiske forklaringen på denne forskjellen, er at skjønnsretten har operert med en komponent som er avhengig av usikkerheten knyttet til den forventede inntektsstrømmen for henholdsvis skogbruk og jordbruk. Investeringer i skogbruket ble ansett for mer sikre enn investeringer i jordbruket.

Til hjelp ved utmåling av bruksverdierstatning for skog har skjønnsrettene tidligere benyttet et tabellverk. Tabellverket ble utarbeidet i 1950-årene, og betegnes som "Det grønne heftet". I heftet var det egne tabeller for beregning av kapitaliseringsrenten. Begrunnelsen for valg av rentesatser har vært betraktninger om usikkerhet tilknyttet avkastningen ved investering $\mathrm{i}$ skogbruket. ${ }^{88}$ Når skjønnsrettene egner å ta høyde for usikkerheten ved fastsettelsen av kapitaliseringsrenten, kan det argumenteres for at dette også bør gjøres av Høyesterett. Problemet er at usikkerheten vil kunne variere avhengig av om det som skal erstattes er tapt fremtidig arbeidsinntekt, inntekt fra forskjellige typer jordbruk, inntekter fra skogbruk mv. Høyesterett måtte i så fall fastsatt egne kapitaliseringsrenter for forskjellige næringer. Dette vil være en tidkrevende oppgave som domstolene ikke bør belemres med.

Som vist tilsier en $\varnothing$ konomisk tolkning av kravet om full erstatning at det tas høyde for usikkerhet knyttet til den forventede inntektsstrømmen ved fastsettelsen av kapitaliseringsrenten. Når den forventede inntekten betraktes som sikker, innebærer dette at den erstatningsberettigede stilles i en bedre situasjon enn tilfellet hadde vært hvis det ikke hadde oppstått en skade eller ekspropriasjon. Hensynet til lik behandling av usikkerhet på erstatningsrettens område, at kapitaliseringsrenten må være generell og hensynet til en enkel løsning tilsier imidlertid at domstolene bør betrakte denne som sikker. Det må dermed godtas en inkonsistens mellom kravet om full erstatning som et $\varnothing$ konomisk og juridisk begrep.

Gøril Bjerkan mener at bevisregelen om sannsynlighetsovervekt kan harmonere med kravet om full erstatning så lenge begrunnelsen for bevisregelen endres. ${ }^{89}$ Hun mener begrunnelsen for bevisregelen bør være at den fremskrevne inntekten er den sikre inntekten som skadelidte er like fornøyd med som den usikre fremtidsinntekten hun hadde før skaden inntrådte. Det at de fremtidige inntektsanslagene er resultat av forhandlinger mellom partene, og at skadelidte har akseptert inntektsanslaget, mener Bjerkan taler i retning å oppfatte anslaget nettopp slik. På denne måten vil inntektsusikkerheten være hensyntatt ved fastsettelsen av den tapte fremtidige inntektsstrømmen. Dette innebærer at det ikke skal tas hensyn til inntektsstrømmen ved fastsettelsen av kapitaliseringsrenten. Løsningen som fremmes av Bjerkan har gode

\footnotetext{
${ }^{88}$ Norges skogeierforbund m. fl. 2006 på side 22.

${ }^{89}$ Bjerkan 2015 på side 7.
} 
grunner for seg i alle tilfeller hvor partene er enige om størrelsen på den tapte inntektsstrømmen, slik som tilfellet var i Kreutzer-dommen. Problemet er kapitaliseringsrenten skal være generell og dekke en rekke ulike tilfeller. Hvis den erstatningsberettigede ikke er enig i størrelsen på de inntektene som skal legges til grunn, vil den alternative begrunnelsen falle sammen.

\subsection{Risiko for manglende innfrielse på ekspropriasjonsrettens område}

I Kreutzer-dommen legger Høyesterett til grunn den samme regelen som ble lagt til grunn i Flåmyra-kjennelsen. På ekspropriasjonsrettens område skal dermed usikkerhet knyttet til den fremtidige inntektsstrømmen fortsatt ikke trekkes inn ved fastsettelsen av kapitaliseringsrenten.

\section{Tilpasningsplikten og valg av investeringsobjekter}

\subsection{Innledning}

Det neste spørsmålet er så hvilke investeringsalternativer som skal legges til grunn for kapitaliseringsrenten. Dette spørsmålet er avgjørende for fastsettelsen av kapitaliseringsrenten, da ulike investeringsalternativer vil gi ulik forventet realavkastning.

Årsaken til den forskjellige avkastningen skyldes blant annet at forskjellige investeringsalternativer inneholder forskjellig grad av usikkerhet. Generelt kan det sies at desto høyere risiko man tar, jo høyere avkastning kan man regne med. Den risikofrie renten er oftest omtalt som den avkastningen man kan få på sikre verdipapirer, gjerne tiårs statsobligasjoner. Statsobligasjoner anses som sikre fordi det er liten risiko for at staten ikke betaler. Usikkerhetskomponenten som knytter seg til renten er dermed minimal, og investering i statsobligasjoner gir dermed en liten forventet avkastning. Investerer man derimot i aksjer, vil den forventede avkastningen være høyere. Dette fordi det er knyttet større usikkerhet til om avkastningen vil inntre. Noen vil få en høyere avkastning og noen vil få en lavere avkastning. Den høyere risiko kompenseres med muligheten for en høyere avkastning.

I Flåmyra-kjennelsen, og senere i Kreutzer-dommen har Høyesterett slått fast at den fremtidige inntektsstrømmen skal betraktes som sikker. Logisk sett tilsier dette at det skal legges sikre investeringsalternativer til grunn for kapitaliseringsrenten, for eksempel statsobligasjoner. Høyesterett velger likevel ikke denne løsningen, som følge av at det oppstilles en tilpasningsplikt ved valget av investeringsalternativer. 
I de påfølgende punktene vil det først vurderes hvorvidt kravet om full erstatning tilsier at det er rom for å oppstille en tilpasningsplikt ved valg av investeringsalternativer. Denne vurderingen vil så bli holdt opp mot tidligere rettspraksis og Kreutzer-dommen. Avslutningsvis vil det spørres om hvilke eventuelle virkninger Høyesteretts vurderinger i Kreutzer-dommen vil ha på ekspropriasjonsrettens område.

\subsection{Tilpasningsplikten og kravet om full erstatning}

Tilpasningsplikten innebærer at den erstatningsberettigede har en plikt til å begrense tapet til den som er ansvarlig for erstatningsutbetalingen. På ekspropriasjonsrettens område er tilpasningsplikten ikke lovfestet, men er utviklet gjennom rettspraksis. Ved utmåling av bruksverdierstatning etter ekspropriasjonserstatningsloven $\S 6$ kan plikten komme inn på to måter: ved avkastningsvurderingen etter $\S 6$ og ved fastsettelsen av kapitaliseringsrenten. Det er tilpasningsplikten som Høyesterett har oppstilt i forhold til kapitaliseringsrenten som vil bli vurdert i det følgende.

Hvis de årlige tap kan anslås med sikkerhet, tilsier dette som nevnt at erstatningsbeløpet bør plasseres på en sikker måte, for eksempel i en bankkonto. ${ }^{90}$ Omvendt, hvis de årlige tap er usikre, bør det legges til grunn at erstatningsbeløpet plasseres på en mer usikker måte, for eksempel i aksjer. Desto mer usikkerhet som er knyttet til tapenes eksistens, desto høyere bør rentefoten settes. På denne måten vil, som vist ovenfor under punkt 6.3 , den erstatningsberettigede stilles i den samme $\varnothing$ konomiske situasjonen som tilfellet er hvis ekspropriasjonen eller den skadevoldende handling ikke hadde funnet sted. Spørsmålet er så om kravet om full erstatning gir rom for å legge til grunn investeringsalternativer som inneholder en større usikkerhetskomponent enn den usikkerheten som knyttet seg til den forventede inntektsstrømmen.

Eide nevner at det i utgangspunktet kan være to grunner til at investeringsalternativene som legges til grunn inneholder en større usikkerhetskomponent. ${ }^{91}$ Den første muligheten Eide nevner er likviditetsfordelen ekspropriaten vil kunne oppnå som følge av at erstatningsbeløpet utbetales som et engangsbeløp. En ekspropriat som for eksempel har mye gjeld, vil kunne nedbetale denne og dermed slippe å betale renter til banken. Så lenge usikkerhetskomponenten i bankens utlånsrente er større enn usikkerhetskomponenten knyttet til de årlige tapene, har engangsutbetalingen medført en fordel for den erstatningsberettigede.

\footnotetext{
${ }^{90}$ Eide 1995 a på side 60.

${ }^{91}$ Eide 2011 på side 11.
} 
Hvis det ikke gjøres et fradrag for denne fordelen, vil ekspropriaten stilles i en bedre situasjon enn tilfellet hadde vært hvis man tenker at ekspropriasjonen ikke hadde funnet sted.

Den andre muligheten Eide nevner er tilfellet hvor ekspropriaten kan forventes å erstatte en lite lønnsom virksomhet med en som er mer lønnsom. Tilpasningsplikten stiller krav om en "fornuftig og forsvarlig plassering av erstatningsbeløpet". ${ }^{92}$ Som Eide skriver må det forutsettes at ekspropriaten hittil ikke har foretatt en fornuftig og forsvarlig plassering for at en større usikkerhetskomponent knyttet til investeringsalternativene skal kunne forsvares. Det kan tenkes at en ekspropriat har en mulighet til å investere i mer lønnsomme deler av sin næring, og at rimelighetsbetraktninger tilsier at dette bør gjøres. En slik vurdering vil imidlertid ikke kunne forsvares ut fra en rent økonomisk tolkning av kravet om full erstatning. Hvis ekspropriasjonen ikke hadde funnet sted ville ekspropriaten fortsatt å plassere sine midler i den "mindre lønnsomme" delen av næringen.

På den annen side må det kunne sies at oppstilling av en tilpasningsplikt vil kunne forsvares ut fra en rent juridisk tolkning av kravet om full erstatning. Tilpasningsplikten som er oppstilt ved påregnelighetsvurderingen etter ekspropriasjonserstatningsloven $\S 5$, kan illustrere dette. Avgjørelsen inntatt i Rt. 1989 s. 1014 (Follum fabrikker AS) gjaldt ekspropriasjon av 30 daa. av en større skogeiendom. Overskjønnet hadde erstattet tomten etter sin verdi som tomtegrunn. Høyesterett kom til at ekspropriaten etter ekspropriasjonen fremdeles hadde tilstrekkelig arealer til å tilfredsstille etterspørselen etter hyttetomter. Dette tilsa at det eksproprierte areal skulle erstattes etter sin verdi som skogareal, som var langt lavere enn verdien som tomtegrunn. Begrunnelsen var "at det ved tapsberegningen i ekspropriasjon legges til grunn at ekspropriaten får innrette seg som en rimelig og fornuftig person". ${ }^{93}$ Overskjønnet ble dermed opphevet. Tilpasningsplikten medførte at ekspropriaten ble tvunget til å benytte en annen investeringsmulighet enn den som ville blitt benyttet hvis ekspropriasjonen ikke hadde funnet sted. Avgjørelsen inntatt i Rt. 1991 s. 1157 (Lillehammer) gjaldt utmåling av salgsverdierstatning ved delekspropriasjon av en eiendom med grusforekomster. Overskjønnet mente tilpasningsplikten medførte at erstatningen skulle baseres på at de eksproprierte grusforekomstene hadde blitt solgt etter at de gjenværende grusforekomster var blitt utnyttet. Dette innebar at erstatningen skulle baseres på den neddiskonterte nåtidsverdi av de antatt fremtidige verdiene på realisasjonstidspunktet. Erstatningsutbetalingen ville dermed bli lavere. Høyesterett sa seg enig med overskjønnet, og uttalte følgende på side 1161:

\footnotetext{
${ }^{92}$ Se for eksempel Rt. 1986 s. 178 på side 186

${ }^{93}$ På side 1017.
} 
"En grunneier har plikt til å innrette seg slik at ekspropriasjonen kan gjennomføres på den rimeligste måte. Så lenge grunneieren settes i den samme økonomiske stilling han ville vært i om ekspropriasjonen ikke hadde funnet sted, har han fått den erstatning han etter loven har krav på."

Dette viser at når det foreligger en alternativ utnyttingsmulighet, og utnyttelse av denne vil redusere erstatningsutbetalingen, kan tilpasningsplikten tilsi at denne muligheten legges til grunn ved erstatningsutmålingen. Det siterte viser at Høyesterett mener at kravet om full erstatning oppfylles selv når det oppstilles en tilpasningsplikt.

Konklusjonen må dermed være at kravet om full erstatning vil kunne gi rom for å legge til grunn investeringsalternativer som inneholder en større usikkerhetskomponent enn den usikkerheten som knyttet seg til den forventede inntektsstrømmen. Problemet er, som det vil fremgå av gjennomgangen nedenfor, at domstolen legger en objektivisert tilpasningsplikt til grunn for valg av investeringsalternativer. Tilpasningsplikten er knyttet til hvordan en alminnelige forstandig ekspropriat vil plassere erstatningsbeløpet. Dette innebærer at det ikke skal vurderes hvilken likviditetsfordel den enkelte ekspropriat vil kunne få som følge av engangsutbetalingen, eller hvilke fornuftige og forsvarlige plasseringer den enkelte ekspropriat bør foreta for å oppnå større avkastning. Enten må det påvises at en engangsutbetaling vil gi ekspropriater flest en likviditetsfordel. Alternativt må det påvises at ekspropriater flest bør foreta en vridning i sine valg av plasseringer til en mer lønnsom del av næringen.

\subsection{Tidligere avgjørelser}

Den første avgjørelsen hvor det eksplisitt ble tatt stilling til spørsmålet om hvilke investeringsalternativer som skal ligge til grunn for kapitaliseringsrenten, er Noem-dommen. Skjønnsretten hadde fastsatt kapitaliseringsrenten til $6 \%$ for dyrket mark og 3,5\% for skog. På de eksproprierte eiendommene (med unntak av en eiendom) ble det drevet kombinert skogbruksdrift og jordbruksdrift. Den ankende part hevdet at det var uholdbart å operere med en forskjellig kapitaliseringsrente for henholdsvis skog- og jordbruk. Ankemotpartene i saken hevdet at det måtte være en sammenheng mellom risikoen $i$ avkastningen for den eksproprierte eiendom og risikoen for investeringsalternativene som ble lagt til grunn for kapitaliseringsrenten, og at skjønnsrettens avgjørelse dermed var riktig.

Førstvoterende, som fikk tilslutning fra flertallet av dommerne, uttalte at utgangspunktet for valg av investeringsalternativer "må være at det skal foretas en fornuftig og forsvarlig 
plassering av erstatningsbeløpet". ${ }^{94}$ Høyesterett vrir problemstillingen, og vurderer hvordan et erstatningsbeløp bør plasseres.

Videre slås det fast at ved ekspropriasjon av jord- eller skogbrukseiendommer, vil det være "rimelig å legge til grunn at reinvestering i næringen vanligvis vil være en naturlig anvendelse av erstatningen". Hvilke deler av næringen som erstatningsbeløpet skal forventes investert i, er ikke en valgrett for ekspropriaten. Førstvoterende uttaler at ekspropriaten ikke kan høres med at "han skal investere i skogen dersom investering i en annen del av hans næring gir bedre avkastning". Ekspropriaten blir dermed pålagt en tilpasningsplikt, ved at det forutsettes at reinvesteringen av erstatningsbeløpet knytter seg til de delene av næringen som gir bedre avkastning. Førstvoterende slår videre fast at det ikke bare skal ses hen til avkastningen ved langsiktige investeringer, men også avkastningen ved kortsiktige investeringer hvis disse investeringene er høyere. Nedbetaling av gjeld nevnes også som et mulig investeringsalternativ.

Videre slår Høyesterett fast at det ikke skal foretas en konkret vurdering av den enkelte eiendom, men at det må legges til grunn en "felles kapitaliseringsrente som er representativ for eiendommer av den art som ekspropriasjonen gjelder". Høyesterett legger dermed en objektivisert tilpasningsplikt til grunn for fastsettelsen av kapitaliseringsrenten. Det foretas imidlertid ingen begrunnelse for hvorfor det oppstilles en tilpasningsplikt ved valg av investeringsalternativer. Uten at noe er sagt må Høyesterett mene at skogbrukere flest vil oppnå en likviditetsfordel ved engangsutbetalingen, eller at skogbrukere flest ikke investerer sine midler i den delen av næringen som gir best avkastning.

Annenvoterende, og talsmann for mindretallet i saken, mente at investeringsalternativene som skal ligge til grunn for kapitaliseringsrenten ikke skulle begrense seg til alternative investeringsmuligheter i næringen, men at man også burde se hen til andre investeringsalternativer. Utgangspunktet måtte være hvordan en "rimelig og fornuftig person kan skaffe seg avkastning av engangserstatningen". ${ }^{95}$ Annenvoterende mente at det måtte legges et bredere spekter av investeringsalternativer til grunn, og forutsatte at erstatningsbeløpet skulle investeres i aksjer, obligasjoner eller bankinnskudd.

Førstvoterende tok ikke eksplisitt standpunkt til hvilken kapitaliseringsrente som ville være riktig i den aktuelle saken. Men Høyesteretts anvisning på at man må se hen til alternative plasseringsmuligheter "i næringen" tilsier at Høyesterett mener at kapitaliseringsrenten som

\footnotetext{
${ }^{94}$ Rt. 1986 s. 178 på side 186.

${ }^{95}$ På side 189.
} 
overskjønnet benyttet for å kapitalisere bruksverdien for dyrket mark, også skal komme til anvendelse ved kapitaliseringen av bruksverdien for skogområdene. Overskjønnet hadde som nevnt benyttet en kapitaliseringsrente på $6 \%$ ved fastsettelsen av erstatningen for dyrket mark.

Når Høyesterett mener at den fremtidige inntektsstrømmen skal betraktes som sikker, tilsier dette at det må legges risikofrie investeringsalternativer til grunn for fastsettelsen av kapitaliseringsrenten. Som nevnt ovenfor under punkt 7.2 kan en tilpasningsplikt føre til at investeringsalternativer med en høyere grad av usikkerhet legges til grunn uten at dette nødvendigvis går på bekostning av kravet om full erstatning. Men Høyesterett begrunner ikke hvorfor tilpasningsplikten må lede til at investeringsalternativene som skal ligge til grunn for kapitaliseringsrenten skal inneholde store usikkerhetskomponenter. Erling Eide anfører tre mulige begrunnelser for hvorfor tilpasningsplikten kan lede i retning av en så høy kapitaliseringsrente. $^{96}$

For det første nevner han muligheten om at Høyesterett mener ekspropriaten må akseptere en høyere usikkerhet enn den usikkerheten som knytter seg til de årlige tapene. En mulig grunn til at høyere usikkerhet må aksepteres kan for det første være at ekspropriaten må regne med å komme i en mer usikker $\varnothing$ konomisk situasjon som følge av ekspropriasjonen. Eide hevder at dette neppe er tilfelle, og at hvis så var tilfelle måtte dette fremgå uttrykkelig av domspremissene. En slik begrunnelse kan umulig forsvares ut fra kravet om full erstatning. En annen mulighet som nevnes er at engangsutbetalingen medfører at ekspropriaten får en likviditetsfordel som ikke ville blitt vunnet hvis man tenker ekspropriasjonen borte. Eide hevder imidlertid at dette ikke kan tjene til begrunnelse uten at det har støtte i empiriske studier. Det er på ingen måte bevist, og det anføres heller ikke av Høyesterett, at flertallet av skogbrukere sliter med likviditetsproblemer eller har likviditetsproblemer som gjør at de må investere i virksomhet som ikke gir den beste avkastningen.

En annen potensiell begrunnelse som Eide anfører er at domstolen antar at ekspropriatene er irrasjonelle i den forstand at de ikke evner å sette sammen gjeld og formue på en best mulig måte. Dette avfeies av Eide med samme begrunnelse som ovenfor. Det finnes ingen empiriske studier som tilsier at skogbrukere er irrasjonelle.

En siste mulig begrunnelse som nevnes er at retten kan overprøve ekspropriatenes preferanser. Antakelsen innebærer at Høyesterett mener at skogeierne har en subjektiv glede av å eie skog, og har derfor investert for mye i skogdriften selv om midlene kunne vært investert i mer

\footnotetext{
${ }^{96}$ Eide 2011 på side 140, 141 og 142.
} 
lønnsomme deler av næringen. Eide avviser også denne mulige begrunnelsen da det ikke foreligger dokumentasjon på at dette faktisk er tilfelle.

I Ølberg-dommen, som gjaldt erstatningsutmålingen ved personskade, legger Høyesterett innledningsvis til grunn det samme utgangspunktet som annenvoterende i Noem-dommen. Det avgjørende for kapitaliseringsrenten måtte være hva "en fornuftig og forsvarlig plassering vil være for en person i skadelidtes situasjon, når det også tas hensyn til at han plikter å begrense sitt tap". ${ }^{97}$ Usikkerheten knyttet til investeringsalternativene skal dermed ikke gjenspeile usikkerheten knyttet til den tapte inntektsstrømmen.

Kapitaliseringsrentens størrelse måtte bestemmes etter en "bred vurdering av de ulike anvendelses- og investeringsmuligheter som foreligger, dog slik at det ikke kan kreves at skadelidte foretar investeringer som det knytter seg noen særlig risiko til." Uttrykket "særlig risiko" er ikke et klart definert begrep, men må gi anvisning på at investeringsalternativene som skal legges til grunn for kapitaliseringsrenten må begrense seg til investeringsalternativer med en lavere grad av risiko. Som eksempler på investeringsalternativer det skal ses hen til nevner førstvoterende fast eiendom, livrente, obligasjoner, aksje- og rentefond, høyrentekonto i bank, nedbetaling av gjeld og fast eiendom. Eide stiller spørsmålstegn ved hvordan Høyesterett kan mene at det ikke knytter seg noen "særlig risiko" til de nevnte investeringsalternativer, da dette ikke gjenspeiler seg i virkeligheten. ${ }^{98}$

Høyesterett presiserer ikke hvordan en "rimelig fornuftig person" vil investere erstatningsbeløpet. Høyesterett nevner bare eksempler på potensielle investeringsalternativer, uten å fastlegge fordelingen av disse. Dette gjør det umulig å vurdere rentefotens størrelse. Det fremstår dermed som et åpent spørsmål hvordan Høyesterett kommer frem til at kapitaliseringsrenten skal være $5 \%$.

I Flåmyra-kjennelsen slår Høyesterett fast at de "investeringsmuligheter som ligger til grunn for fastsettelsen av kapitaliseringsrenten i personskadesakene, er det nærliggende å trekke inn også når det skal foretas en slik objektivisert vurdering som etter praksis ved avståelse av skog". ${ }^{99}$ Dette innebærer at Høyesterett tilsidesetter investeringsalternativene som flertallet i Noem-dommen la til grunn. Her ble det som nevnt forutsatt reinvestering "i næringen". Høyesteretts standpunkt i Flåmyra-kjennelsen er lagt til grunn i senere avgjørelser fra

\footnotetext{
${ }^{97}$ Rt. 1993 s. 1524 på side 1532.

${ }^{98}$ Eide 2011 på side 148.

${ }^{99}$ Rt. 1994 s. 557 på side 562.
} 
Høyesterett. ${ }^{100}$ Dette innebærer at det skal opereres med de samme investeringsalternativer på ekspropriasjonsretten og personskaderettens område.

Kapitaliseringsrenten på $5 \%$ er blitt benyttet på begge rettsområdene frem til høsten 2014. I teorien er rentefoten blitt kritisert som følge av at den er satt for høyt, og sånn sett ikke gir den erstatningsberettigede full erstatning. ${ }^{101}$ De nevnte dommene gir som vist ingen god forklaring på hvorfor kapitaliseringsrenten skal settes så høyt.

Når den årlige forventede inntektsstrømmen skal betraktes som sikker, tilsier dette at investeringsalternativene som skal legges til grunn er risikofrie. Investeringsalternativene som Høyesterett nevner kan ikke anses som risikofrie. Dette skulle tilsi at Høyesterett mener en tilpasningsplikt kan forsvare den høyere risiko. Som Eide nevner, finnes det ikke dokumentasjon på at engangsutbetalingen vil gi ekspropriater flest en likviditetsfordel, eller at de investerer sine midler i mindre lønnsomme deler av sin næring. På ekspropriasjonsrettens område er det dermed ikke grunnlag for å oppstille en tilpasningsplikt. Høyesterett ser det imidlertid på en annen måte. Det avgjørende er ikke at usikkerheten knyttet til den tapte inntektsstrømmen skal gjenspeile seg i usikkerheten knyttet til investeringsalternativene som skal legges til grunn. Spørsmålet er kun hva en "fornuftig og forsvarlig" plassering av erstatningsbeløpet vil være.

Når Høyesterett velger hvilke investeringsalternativer som skal ligge til grunn helt uavhengig av usikkerheten knyttet til inntektsstrømmen som skal erstattes, og det ikke finnes grunnlag for å oppstille en tilpasningsplikt, medfører dette at den erstatningsberettigede ikke får sitt fulle tap erstattet.

Hvor stor del av erstatningsbeløpet som forventes investert i de ulike investeringsalternativene er ikke mulig å lese ut av dommene. Oppgaven ved å vurdere rentesatser frem i tid er en vanskelig Øvelse, men blir umulig når investeringsporteføljen vurderingen skal baseres på ikke blir nærmere fastlagt.

\subsection{Tilpasningsplikten og valg av investeringsobjekter i Kreutzer-dommen}

Spørsmålet er så om Høyesterett sin begrunnelse i Kreutzer-dommen tilsier at den erstatningsberettigede får full erstatning.

\footnotetext{
${ }^{100}$ For eksempel Rt. 1997 s. 428 og Rt. 2008 s. 195.

${ }^{101}$ Eide 2011 på side 149, Hylland 1995 på side 54.
} 
De sakkyndige for Høyesterett hadde lagt til grunn at forventede kostnader og tapte inntekter i en nåverdiberegning kunne forventes å ha en relativt lav risiko. Fastsettelsen av kapitaliseringsrenten var derfor avhengig av valget av en risikofri normalrente for fremtiden. De sakkyndige la til grunn en investeringsportefølje som innebar at $80 \%$ av erstatningsbeløpet skulle investeres i norske statsobligasjoner, $10 \%$ i norske aksjer og $10 \%$ i utenlandske aksjer.

Høyesterett stilte først spørsmål om det er riktig å forutsette en slik investeringsportefølje. Førstvoterende understrekte at dette er et rettslig spørsmål, da det er "tale om hvilken risiko det er rimelig å forvente at en skadelidt skal ta for å oppfylle sin tapsbegrensningsplikt". ${ }^{102}$ Førstvoterende viser så til et sitat fra Ølberg-dommen og slutter fra denne at en skadelidt normalt må være forberedt på å ta noe større risiko enn de sakkyndige hadde forutsatt. Høyesterett legger dermed til grunn den samme vurderingen som i tidligere avgjørelser. Sammenhengen mellom usikkerheten knyttet til den tapte inntektsstrømmen og usikkerheten knyttet til investeringsalternativene som blir lagt til grunn, er irrelevant ved fastsettelsen av kapitaliseringsrenten.

Høyesterett anfører så fire argumenter for at porteføljen som skal legges til grunn for kapitaliseringsrenten må inneholde en større grad av usikkerhet enn de sakkyndige hadde forutsatt.

For det første nevner Høyesterett at kapitaliseringsrenten skal dekke en rekke ulike situasjoner, og at den derfor ikke bare kan basere seg på Kreutzer sin situasjon. ${ }^{103}$ Høyesterett viste her til uttalelser fra de sakkyndige, som hadde uttalt at dersom den skadelidte var eldre og uførhetsgraden lavere, ville det være naturlig å ta noe større risiko enn det de hadde lagt til grunn.

For det andre viser førstvoterende til at trygden har en inntektsgaranti som innebærer at skadelidte vil klare seg økonomisk selv om erstatningen ikke skulle gi den avkastningen som er forutsatt. Det er vanskelig å forstå hvordan sikkerhetsnettet som trygden gir kan benyttes som et argument for at investeringsalternativene som legges til grunn for kapitaliseringsrenten skal inneholde en større grad av usikkerhet. Målet må være at kapitaliseringsrenten gir skadelidte full erstatning, slik at sikkerhetsnettet ikke benyttes.

\footnotetext{
102 Avsnitt 90.

${ }^{103}$ Avsnitt 93.
} 
For det tredje viser førstvoterende til et sakkyndig vitne som Kreutzer hadde ført for lagmannsretten. ${ }^{104}$ I sin skriftlige erklæring hadde han gitt uttrykk for at en plassering hovedsakelig i statsobligasjoner, men med en tredjedel i aksjer, "ikke er en veldig risikopreget tilpasning". Det er vanskelig å se hvordan dette kan brukes som et argument for at den skadelidte må ta større risiko ved plassering av erstatningsbeløpet. I sitatet fra Ølbergdommen som førstvoterende slutter seg til, fremgår det at "det ikke kan kreves at skadelidte foretar seg investeringer som det knytter seg til noen særlig risiko til". Uttalelsen fra den sakkyndige harmonerer godt med uttalelsene i Ølberg-dommen. Hvis Høyesterett mener at det må legges en mer risikofylt portefølje til grunn enn det som uttales av det sakkyndige vitne, kan dette tyde på et $\varnothing$ nske om å gjøre tapsbegrensningsplikten strengere enn det som ble lagt til grunn i Ølberg-dommen. En slik slutning er imidlertid for usikker, da dette ikke nevnes uttrykkelig av Høyesterett.

For det fjerde viser Høyesterett til en skriftlig forklaring fra et sakkyndig vitne som ble ført av en av partene for Høyesterett. Her hadde han pekt på at en fordeling med 50/50 i aksjer og obligasjoner er nokså vanlig ved forvaltning av pensjonsmidler. Mye kan tyde på at Høyesterett anser denne porteføljen som mer korrekt, men at det må gjøres noen korreksjoner.

Høyesterett mener at den sikre delen av porteføljen også bør inneholde andre typer obligasjoner enn statsobligasjoner. ${ }^{105}$ Forutsetningen var at også disse obligasjonene ble ansett som "svært sikre". Som eksempel ble det nevnte obligasjoner med fortrinnsrett utstedt av norske banker. Den sikre delen skal dermed gjøres noe mer usikker.

I tillegg til dette mener Høyesterett at det må legges til grunn at skadelidte investerer erstatningsbeløpet i bolig, enten ved kjøp av bolig eller ved nedbetaling av gjeld på egen bolig.

Høyesterett begrunner ikke boliginvestering $\mathrm{i}$ at engangsutbetalingen vil gi den skadelidte en likviditetsfordel. De sakkyndige for Høyesterett hadde ikke tatt med en slik fordel i sine beregninger. Gode grunner kan imidlertid tilsi at skadelidte flest vil oppnå en likviditetsfordel ved engangsutbetalingen. I Norge må det anses som vanlig at man på et tidspunkt i livet eier sin egen bolig, og at man normalt må oppta lån for denne anskaffelsen. Ved å få hele erstatningsbeløpet utbetalt som engangsbeløp, muliggjør denne nedbetaling av lån på egen bolig eller at man unngår å ta opp lån ved kjøp av bolig. Dette ville ikke vært mulig hvis man tenker at engangsutbetalingen ikke hadde funnet sted. Ved å unngå et lånebeløp vil man

\footnotetext{
${ }^{104}$ Avsnitt 95.

${ }^{105}$ Avsnitt 96.
} 
dermed også unngå å betale renter på dette lånet. Så lenge utlånsrenten inneholder en større usikkerhetskomponent enn usikkerheten knyttet til de fremtidige tapene, vil skadelidte stilles i en bedre situasjon enn tilfellet var hvis man tenker skaden borte. I motsetning til hva som er tilfelle for typiske ekspropriater, er det mulig å bygge på en antakelse om at engangsutbetalingen gjør at skadelidte vil kunne sette sammen sin gjeld og formue på en mer lønnsom måte. Det foreligger imidlertid ingen dokumentasjon på at dette er tilfelle.

Høyesterett konkluderer aldri med hvilken investeringsportefølje som skal ligge til grunn for kapitaliseringsrenten. Mye kan tyde på at Høyesterett mener at en fordeling 50/50 mellom sikre og mer usikre investeringsalternativer skal danne grunnlaget. Etter dette trekker Høyesterett imidlertid inn andre obligasjoner og boliginvestering, uten å nevne hvordan dette skal påvirke fordelingen. I mangel av fastere fordelingen vil det være en umulig oppgave å beregne en fremtidig renteavkastning.

Som i tidligere avgjørelser tar Høyesterett ikke utgangspunkt i at de investeringsalternativene som skal legges til grunn for kapitaliseringsrenten bør gjenspeile den usikkerheten som knytter seg til de tapene som skal erstattes. Det avgjørende for valg av investeringsalternativer er hvordan erstatningsbeløpet bør plasseres. Ved å ta feil utgangspunkt vil vurderingen av investeringsalternativer ikke lede til at kravet om full erstatning oppfylles.

\subsection{Tilpasningsplikten og valg av investeringsobjekter på ekspropriasjonsrettens område}

Spørsmålet er så hvilke investeringsalternative som skal ligge til grunn for kapitaliseringsrenten på ekspropriasjonsrettens område.

I Kreutzer-dommen legger Høyesterett til grunn at tilpasningsplikten tilsier at en del av erstatningsbeløpet skal plasseres i bolig. Som vist ovenfor kan gode grunner tale for at en skadelidt vil kunne oppnå en likviditetsfordel ved engangsutbetalingen, og at dermed boliginvestering vil kunne være et relevant investeringsalternativ. Det samme kan ikke sies å være tilfelle på ekspropriasjonsrettens område. Som vist ovenfor er det ikke noe som tilsier at typiske ekspropriater vil oppnå en likviditetsfordel ved engangsutbetalingen. Dette tilsier at boliginvestering ikke skal legges til grunn som investeringsalternativ for fastsettelsen av kapitaliseringsrenten på ekspropriasjonsrettens område.

Uavhengig av dette viser rettspraksis fra tidligere at det ved fastsettelsen av kapitaliseringsrenten på ekspropriasjonsrettens område skal sees hen til de 
investeringsalternativer som legges til grunn på personskadeerstatningens område. ${ }^{106}$ Hvorfor dette skal gjøres, begrunnes ikke nærmere i avgjørelsene. Den mest sannsynlige årsaken er at Høyesterett vurderer hvordan et erstatningsbeløp bør plasseres, og at denne vurderingen faller likt ut for skadelidte og ekspropriater.

Konklusjonen må dermed være at de samme investeringsalternativene som blir lagt til grunn i Kreutzer-dommen også vil bli lagt til grunn ved fastsettelsen av kapitaliseringsrenten på ekspropriasjonsrettens område.

Det å oppstille en tilpasningsplikt uten at det er grunnlag for det, kan få følger som ikke er $\emptyset$ nskelige. Et av hensynene bak en tilpasnings- eller tapsbegrensningsplikt er å sørge for effektiv ressursutnyttelse. Det samme hensyn hviler bak ekspropriasjonsinstituttet, som åpner for at fast eiendom ved tvang kan plasseres hos den som kan utnytte eiendommen verdimessig på best mulig måte. Ved å oppstille en tilpasningsplikt uten at det er grunnlag for det, kan dette potensielt medvirke til ineffektiv ressursutnyttelse. Dette kan illustreres med et eksempel: En jordbruker har en årlig nettoavkastning på 100000 kroner, og vil fortsette driften i ti år frem i tid. Investeringer i næringen gir en forventet avkastning (inkludert usikkerhet) på 2,5\%. Den korrekte nåverdien av den fremtidige inntektsstrømmen er 875000 kroner. Eiendommen eksproprieres med en kapitaliseringsrente på $4 \%$, hvor det er innlagt et tillegg som følge av ekspropriatens tilpasningsplikt. Jordbrukeren, nå ekspropriaten, vil i dette tilfelle få utbetalt 811000 kroner. Eksproprianten og myndigheten som avgjør om ekspropriasjon skal skje, betrakter kun erstatningssummen på 811000 kroner. Så lenge avgjørende myndighet mener eksproprianten kan skape større verdier enn denne summen, vil ekspropriasjon kunne skje. Ekspropriasjon vil dermed kunne finne sted til en verdi lavere enn den ekspropriaten kan skape. Eiendommen vil i disse tilfellene kunne plasseres hos den som verdsetter arealet minst.

\section{Rentefotens størrelse}

\subsection{Rentefotens størrelse i Kreutzer-dommen}

De sakkyndige økonomene som var oppnevnt av Høyesterett i Kreutzer-dommen, hadde i sine erklæringer lagt til grunn at forventet avkastning og risikoprofil for utvalget av investeringsalternativer, ville være avhengig av tidshorisonten anslagene skulle knyttes til. De sakkyndige la til grunn at norsk økonomi er inne i en lavrenteperiode, og at denne vil vare

\footnotetext{
${ }^{106}$ Rt. 1994 s. 557, Rt. 1997 s. 428 og Rt. 2008 s. 195.
} 
noen år fremover. Det ble videre hevdet at på lengre sikt vil rentenivået normalisere seg. Basert på investeringsalternativene som de la til grunn, lå gjennomsnittet av anslagene på 2,43\%. Høyesterett konkluderte med at en kapitaliseringsrente på $4 \%$ skulle legges til grunn. ${ }^{107}$

Avgjørende for valget av rentenivå var for det første at det er lite ønskelig at domstolene endrer renten ofte. Argumentet mot stadig endring av kapitaliseringsrenten var at dette ville føre til en komplisering og fordyring av erstatningsoppgjørene. Når renten forutsettes å bli stående i lang tid fremover, mener Høyesterett at det dermed ikke kan tas høyde for at rentenivået vil være lavere de nærmeste årene. Høyesterett legger dermed begrenset vekt på at den enkelte skadelidte får full erstatning. Målet er at flest mulig fremtidige skadeoppgjør vil tilfredsstille kravet om full erstatning.

Videre legger Høyesterett vekt på at anslagene rundt den fremtidige avkastningen i stor grad er beheftet med usikkerhet. Høyesterett mener dette tilsier forsiktighet med å gjøre større endringer i forhold til tidligere rettstilstand.

Høyesterett erkjenner at et rentenivå på 4 \% er for høyt ut fra dagens økonomiske situasjon. Så lenge det er domstolenes oppgave å fastsette kapitaliseringsrenten, må de hensynene som Høyesterett trekker frem kunne forsvares. Kapitaliseringsrenten kan ikke følge svingningene i rentenivået. Som Bjerke nevner, så er imidlertid resultatet av dommen "svært kritikkverdig". ${ }^{108}$ Som følge av det gjeldende lave rentenivået, som forventes opprettholdt noen år frem i tid, vil den høye kapitaliseringsrenten medføre at flere erstatningsberettigede får for lave erstatningsutbetalinger.

Som vist ovenfor tilsier det forhold at den tapte fremtidige inntektsstrømmen betegnes som sikker at det skal legges sikre investeringsalternativer til grunn for kapitaliseringsrenten. De tre sakkyndige som var oppnevnt av Høyesterett anslo fremtidig risikofri realrente til et sted mellom 1,5 \% - $2 \% .{ }^{109}$ Hvis det hadde vært en logikk i resonnementet til Høyesterett, og anslagene til de sakkyndige er riktige, skulle kapitaliseringsrenten ligget på ca. $2 \%$. En slik kapitaliseringsrente ville gitt langt større erstatningsutbetalinger.

\footnotetext{
${ }^{107}$ Avsnitt 99.

${ }^{108}$ Bjerkan 2015 på side 7.

${ }^{109}$ Johnsen 2014 på side 2, Moen 2014 på side 5 og Holden 2014 på side 3.
} 


\subsection{Rentefotens størrelse på ekspropriasjonsrettens område}

Høyesterett har som nevnt konsekvent lagt til grunn at den samme kapitaliseringsrenten som hovedregel skal legges til grunn også på ekspropriasjonsrettens område. Det er ingen forhold ved Kreutzer-dommen som tilsier at rettstilstanden ikke vil opprettholdes. Det må dermed legges til grunn at kapitaliseringsrenten som vil bli benyttet $i$ fremtidige ekspropriasjonserstatningssaker som hovedregel vil være på $4 \%$.

Målet for avhandlingen har som nevnt innledningsvis ikke vært å vurdere om størrelsen på kapitaliseringsrenten oppfyller kravet om full erstatning. Det skal imidlertid nevnes at en kapitaliseringsrente på $4 \%$ samsvarer med kalkulasjonsrenten som benyttes ved verdiberegningen ved konsesjon. Kjøp av ny skogseiendom eller jordbrukseiendom krever ofte konsesjon, og i saksbehandlingen gjøres det en verdiberegning etter nærmere fastsatte regler. I Rundskriv M-7/2002 (skogbruk) og M-4/2004 (jordbruk) fastslår Landbruksdepartementet at det ved verdiberegningen skal benyttes en kalkulasjonsrente på $4 \%$. Når kapitaliseringsrenten som benyttes ved utmåling av bruksverdierstatning for skogog jordbruk samsvarer med denne kalkulasjonsrenten, vil ekspropriaten ha mulighet til å kjøpe en tilsvarende eiendom som den eksproprierte. Ekspropriaten vil da stilles i samme $\emptyset$ konomiske situasjon som tilfellet var før ekspropriasjonen. Dette forutsetter imidlertid at det er mulig å kjøpe en tilsvarende eiendom i nærheten av avstått eiendom. Tilgangen på skogeiendom er begrenset, og det vil være usikkerhet knyttet til tidspunktet for når en erstatningseiendom vil være tilgjengelig. ${ }^{110}$ Det samme må antas å gjelde jordbrukseiendom. Det er dermed vanskelig å se at konsesjonsrenten skal være et mål på hvorvidt en skog- eller jordbruker får full erstatning ved fastsettelsen av kapitaliseringsrenten ved ekspropriasjon.

\section{Konklusjon}

Avhandlingen har for det første vist at kravet om full erstatning ved fastsettelsen av kapitaliseringsrenten tilsier at det må benyttes en realrente ved denne fastsettelsen. I Kreutzerdommen gir Høyesterett klart uttrykk for at kapitaliseringsrenten må gi full inflasjonsbeskyttelse. Høyesteretts vurdering av inflasjonsbeskyttelse tilsier dermed at ekspropriaten får full erstatning.

Hvis det forventes en fremtidig reallønnsvekst, innebærer kravet om full erstatning at det må tas høyde for dette ved erstatningsutmålingen. Dette bør ikke gjøres ved fastsettelsen av kapitaliseringsrenten, da reallønnsveksten bare knytter seg til bruttoinntekten. For å unngå at

\footnotetext{
${ }^{110}$ Norges Skogeierforbund m. fl. 2006 på side 9.
} 
det må benyttes to kapitaliseringsrenter, bør kompensasjon for forventet reallønnsvekst trekkes inn ved fastsettelsen av de årlige tap i kronebeløp. Det må dermed anses som riktig at Høyesterett i Kreutzer-dommen ser bort fra reallønnsveksten ved fastsettelsen av kapitaliseringsrenten.

Kravet om full erstatning innebærer at usikkerheten knyttet til den tapte inntektsstrømmen gjenspeiler seg i et tilsvarende risikotillegg ved fastsettelsen av kapitaliseringsrenten. Hvis det sees bort fra denne usikkerheten vil ekspropriaten får mer enn sitt fulle tap erstattet. Gode grunner taler imidlertid for at man fastholder regelen om sannsynlighetsovervekt, og at de årlige tapene betraktes som sikre. Logikken tilsier dermed at det skal benyttes en risikofri realrente ved fastsettelsen av kapitaliseringsrenten. Dette gjøres ikke av Høyesterett. Høyesterett oppstiller en tilpasningsplikt, og det avgjørende for kapitaliseringsrenten er hvilken avkastning man kan få ved en fornuftig og forsvarlig plassering av erstatningsbeløpet. Når utgangspunktet for vurderingen er feil, vil dette lede til en uriktig kapitaliseringsrente. Vurderingen Høyesterett legger opp til vil dermed føre til at kravet om full erstatning ikke oppnås. Uavhengig av dette viser avhandlingen at det ikke er rom for å oppstille en objektivisert tilpasningsplikt ved fastsettelsen av kapitaliseringsrenten på ekspropriasjonsrettens område. Når Høyesterett likevel gjør dette, forsterkes inntrykket av at kapitaliseringsrenten er feil beregnet.

Høyesteretts vurderinger knyttet til kapitaliseringsrenten tilsier dermed at ekspropriater ikke får full erstatning ved utmåling av bruksverdierstatning etter ekspropriasjonserstatningsloven $\S 6$.

Konklusjonen tydeliggjør at det ikke bør være domstolenes oppgave å fastsette kapitaliseringsrenten. Høyesterett gir også klart utrykk i både Ølberg-dommen og Kreutzerdommen for at kapitaliseringsrenten bør fastsettes ved lov eller forskrift. Fordelene ved dette er mange. For det første vil kapitaliseringsrenten være mer elastisk, ved at endringer kan gjøres så fort det foreligger nye vurderinger av fremtidig rentenivå. For det annet, som Bjerkan nevner, vil kapitaliseringsrenten kunne knytte seg til tidshorisonten for den tapte inntektsstrømmen. ${ }^{111}$ Kapitaliseringsrenten vil da kunne ta høyde for forventede svingninger i rentenivået. Tapene som oppstår i de neste ti årene vil kunne kapitaliseres med en lavere kapitaliseringsrente enn tapene som vil oppstå fra ca. ti år frem og utover. Det vil videre være mulig å operere med et tillegg knyttet til risikoen i forskjellige næringer. Samlet vil dette bidra til å minimere forskjellen mellom kravet om full erstatning som et økonomisk begrep og som et juridisk begrep.

\footnotetext{
${ }^{111}$ Bjerkan 2015 på side 7.
} 


\section{Norske lover}

Grl

orvl

skl

\section{Litteratur}

Bjerkan 2015

Eide 1995a

Eide 2011

Hylland 1995

Kjønstad 2003

Lødrup m. fl. 2009

Norges Skogeierforbund m. fl. 2006

Nygaard 2007

Stordrange m. fl. 2000

Syse m. fl. 2011
Kongeriket Noregs Grunnlov, 17. mai 1814

Lov 6. april $1984 \mathrm{nr} 17 \mathrm{om}$ vederlag ved oreigning av fast eigedom (ekspropriasjonserstatningslova)

Lov 13. juni $1969 \mathrm{nr} 26$ om skadeserstatning (skadeserstatningsloven)

Bjerkan, Gøril. Den vanskelige kapitaliseringsrenten Rt. 2014 s. 1203. Nytt i privatretten 2015 nr 1, s. 5-7

Eide, Erling. Valg av investeringsobjekt for erstatningsbeløp. Lov og Rett. 1995, s. 58-64

Eide, Erling. Kapitaliseringsrenten og Hфyesteretts misforståelse. Tidsskrift for Erstatningsrett 2011, s. 125-162

Hylland, Aanund. Renter og kapitalisering. Kommentarer til en avgjørelse i Høyesterett. Lov og Rett 1995, s. 40-57

Asbjørn Kjønstad. Erstatningsretten i utvikling. Oslo, Universitetsforlaget 2003

Lødrup, Peter og Morten Kjelland. Larebok i erstatningsrett. 6. utg. Oslo, Gyldendal Akademisk 2009

Norges Skogeierforbund, Norskog og Svenkerud Skog AS. Grunnlag for riktig kalkulasjonsrente i skogerstatninger. Oslo 2006

Nygaard, Nils. Skade og ansvar, 6. utg. Bergen, Universitetsforlaget 2007

Stordrange, Bjørn og Lyngholth, Ove Chr.

Ekspropriasjonserstatningsloven, kommentarutgave, 3. utg.

Oslo, Universitetsforlaget 2000

Syse, Aslak, Kjelland, Morten og Jørstad, Rolf Gunnar.

Pasientskaderett. Oslo, Gyldendal Akademisk 2011 
Innst. 1971

NOU 1994:20

NOU 2011:16

M-7/2002 (R-994)

M-4/2004 (R-1075)
Innstilling fra Erstatningslovkomitéen. Komité til i nordisk samarbeid å utrede spørsmålet og eventuelt komme med forslag til nye lovbestemmelser om erstatning for tap av forsørger og for tap i framtidig erverv.

Personskadeerstatning

Standardisert personskadeerstatning

Endringer i rundskriv M-3/2002 - Priser på landbrukseiendommer ved konsesjon Kapitaliseringsrentefot m.m. for skog

Endringer i rundskriv M-3/2002 - Priser på landbrukseiendommer ved konsesjon. Kapitaliseringsrentefot på jord og nedre beløpsgrense for prisvurdering ved konsesjonsbehandling av bebygd eiendom

\section{Publiserte avgjørelser}

$\begin{array}{ll}\text { Rt. } 1981 \text { s. } 138 & \text { Sevaldsen } \\ \text { Rt. } 1986 \text { s. } 178 & \text { Noem } \\ \text { Rt. } 1989 \text { s. } 1014 & \text { Follum Fabrikker AS } \\ \text { Rt. } 1991 \text { s. } 1157 & \text { Hovemoen } \\ \text { Rt. } 1992 \text { s. } 217 & \text { Ulvåkjølen } \\ \text { Rt. } 1993 \text { s. } 1524 & \text { Ølberg } \\ \text { Rt. } 1993 \text { s. } 1538 & \text { Horseng } \\ \text { Rt. } 1994 \text { s. } 557 & \text { Flåmyra } \\ \text { Rt. } 1997 \text { s. } 428 & \text { Torsæterkampen } \\ \text { Rt. } 2008 \text { s. } 195 & \text { Gråfjellet-kjennelsen } \\ \text { Rt. } 2014 \text { s. } 1203 & \text { Kreutzer }\end{array}$


Sakkyndigerklæringer

Moen m. fl. 2014

Holden, Steinar, Johnsen, Thore og Moen, Espen R. Kapitaliseringsrenten, Sakkyndigrapport til Norges Høyesterett, Kreutzer-dommen

Johnsen 2014

Johnsen, Thore. Vedlegg til sakkyndig rapport i HR sak $604 / 2014$

Moen 2014

Moen, Espen R. Vedlegg til sakkyndig rapport i HR sak $604 / 2014$

Holden 2014

Holden, Steinar. Kapitaliseringsrenten - punkt 4 og 5 